Max-Planck-Institut für demografische Forschung

Max Planck Institute for Demographic Research

Konrad-Zuse-Strasse 1 - D-18057 Rostock · GERMANY

Tel +49 (0) 3812081 - 0; Fax +49 (0) 3812081 - 202;

http://www.demogr.mpg.de

MPIDR WORKING PAPER WP 2006-003

FEBRUARY 2006

\title{
On the structural value of children and its implication on intended fertility in Bulgaria
}

Christoph Bühler (buehler@demogr.mpg.de)

This working paper has been approved for release by: Vladimir M. Shkolnikov (shkolnikov@ demogr.mpg.de), Head of the Laboratory for Demographic Data.

(C) Copyright is held by the authors.

Working papers of the Max Planck Institute for Demographic Research receive only limited review. Views or opinions expressed in working papers are attributable to the authors and do not necessarily reflect those of the Institute. 
On the Structural Value of Children and

its Implication on Intended Fertility in Bulgaria

Christoph Bühler

Rostock, February 2006

Christoph Bühler

Max Planck Institute for Demographic Research

Konrad Zuse Str. 1

18057 Rostock, Germany

Tel: $+49(0) 381 / 2081-174$

Fax: +49 (0)381/2081-474

E-mail: Buehler@demogr.mpg.de 


\begin{abstract}
Personal networks receive increasing recognition as structural determinants of fertility. However, the network perspective also helps to explain personal motivations for having children. Using theories of interpersonal exchange and of the value of children, it is argued that children can substantively alter and improve their parents' social networks. Individuals perceive this potential advantageous development as a structural benefit and consider this value in their reproductive decisions. Data from Bulgaria, collected in 2002, support this argument. The intentions of females and males to have a first or second child are positively influenced by at least one structural value. Women's intentions are promoted by the prospect that a child will bring their parents and relatives closer or will strengthen the bond with the partner. Male's intentions are closely associated with the expectation that a child will improve their security at old age.
\end{abstract}




\section{Introduction}

The assessment of fertility as an outcome of purposeful decision-making has become a widely used model to analyze individual reproductive behavior. One initial position of this model is that individuals decide and act on the basis of their perceptions of the current situation and their expectations of the future (Turchi 1975). These perceptions and expectations can be integrated into micro-analytic theories of decision-making by representing them as subjective fertility-related costs and benefits (Hollerbach 1983, Bulatao and Arnold 1977). Consequently, individuals decide to have a first or another child when they assume that the benefits provided by the child outweigh its expected costs to a maximum or satisficing extent (Fawcett 1978, Townes et al. 1977).

Various socio-economic and psychological approaches address particular costs and benefits of having children and show their significance for reproductive intentions and behavior. The Theory of the Value of Children, however, aims to consider all positive and negative incentives that matter in fertility-related decision-making. Although the theory has its roots in psychology, it incorporates a broad variety of economic, social, and cultural dimensions. It therefore offers an integrative view of the motivational determinants of fertility, considering both the personality of the individual actor and the structures of the social environment (Nauck 2005, Hoffman and Hoffman 1973). By focusing on values, i.e., the benefits individuals expect to receive from a child, the theory makes a substantial contribution to the understanding of the processes of declining fertility and to explanations of why people in modern societies still want to have children (Hoffman 1987, Hoffman and Manis 1979, Arnold et al. 1975).

A central aspect of the values supplied by children is their relational foundation. Parents receive joy, satisfaction, support, or old age security on the basis of the direct relationships with their children. On a different dimension, children change their parents' relationships with relatives or other members of the social environment, thus improving their parents' social status or simplifying their access to supportive resources. This relational character of child-induced benefits specifies, on the one hand, the structural preconditions of the value of children. On the other hand, it helps to understand individuals' motivations for having children, which rest on the expectation that children alter their social networks in an advantageous way. Actors are aware of children as possible direct or indirect sources of benefits and they may purposefully intend to be provided with these benefits with the birth of a child.

The paper intends to specify the theoretical background of these child-related structural evaluations. Starting from the dynamic association between network structure and individual action, it is argued that social networks determine reproductive behavior but that fertility outcomes lead to intended or unintended changes in individual social networks. As personal relationships are expressions of interpersonal transfers and exchange, changes in social networks always induce alterations in the related exchange processes. These changes build the foundation both for 
the provision of child-related benefits and for individuals' positive structural evaluations of having children. Children become direct exchange partners of their parents and alter the status, power, social recognition, or perception of their parents by simultaneously changing their parents' exchange relationships with relatives, friends, or other members of the social environment.

In its empirical part, the paper intends to analyze the relevance of the structural value of children to reproductive decision-making by testing its impact on fertility intentions of Bulgarian citizens. To our knowledge, an explicit examination of individuals' evaluations of children as a means to improve their social environments was up to now only performed with data from the U.S. (Schoen and Tufis 2003, Schoen et al. 1997). However, results from different social and cultural settings are needed to learn more about the general importance of this kind of evaluation.

These considerations lead to the following structure of the paper. The subsequent theoretical section (Section 2) mainly discusses the structural value of children and presents at its end some arguments about the significance of intentions in the process of reproductive decisionmaking. This is followed by a brief description (Section 3) of the Bulgarian data, its sample, and the variables used in the analyses. Section 4 presents, firstly, the results of descriptive analyses about the respondents' fertility intentions and their child-related structural values and, secondly, discusses the impacts of these values on the individual intention to have a first or second child. Section 5 provides a concluding discussion.

\section{Theoretical considerations}

\subsection{The structural value of children}

The Theory of the Value of Children intends to understand fertility as an outcome of purposeful decision-making by referring to parental needs being met by children (Hoffman and Hoffman 1973). Accordingly, individuals decide to have a child if the subjectively expected benefits provided by the child outweigh its expected costs (Bulatao and Arnold 1977). The theory places a special emphasis on benefits in order to explain why people purposefully intend to have children. Hoffman and Hoffman (1973) developed a variety of values on the basis of psychological and economic needs. According to them, individuals positively evaluate children because they give adult status to and enhance the social identity of the parents, they expand the Self of the mother and father, they are a visible expression of the fulfillment of cultural moral orders, strengthen ties within the family, give their parents the opportunity for change and new experiences, increase the power and influence of one or both of their parents, enlarge their parents' prestige and status, and generate income for their parents' households.

As subsequently will be shown, central aspects of child-related values rest on interpersonal relationships. Children may provide benefits to their parents on the basis of their direct relationships with them. Moreover, the new status of parenthood or of being a parent of a growing 
family enables changes in the parents' relationships with family members or the wider social environment in an advantageous way.

\subsubsection{Social networks, interpersonal exchange, and child-related benefits}

Personal relationships and structures of social networks receive increasing recognition in studies on reproduction. Research in this field perceives fertility-related intentions or behavior to be significantly influenced by the social networks individuals are embedded in (Bernardi, von der Lippe, and Keim 2005, Bühler and Fratczak 2005, Bühler and Philipov 2005, Bühler and Kohler 2004, Bernardi 2003, Casterline 2001, Kohler 2001, Kohler, Behrman, and Watkins 2001, Montgomery and Casterline 1996). However, the link between social networks and behavior is not an exclusively deterministic one. Theories of structural action propose an association of mutual causality (Schweizer 1996, Leydesdorff 1991, Burt 1982). Social networks influence individual action, but performing this activity causes intended or unintended alterations to these networks.

This dynamic link is observable in particular in the context of demographic events. From a structural point of view, marriage rests on social networks which, for example, give two actors the opportunity to meet or provide the material resources needed for marriage. However, being married leads to significant changes in the networks of the marriage partners. It does not only add a husband or wife to their personal networks, but also establishes relationships with the partner's family members and friends (van der Poel 1993, Hurlbert and Acock 1990, Fischer 1982). Personal relationships are a significant cause of migration (Palloni et al. 2001, Haug 2000), but to migrate entails both a waning and a loss of personal relationships at the former place of residence and access to new social circles at the new place of living.

A similar situation applies to fertility. Social networks influence reproduction, but having a child also changes the personal relationships of the parents in various ways. There is the direct implication of the child as a new and highly significant actor. Furthermore, a child alters the nature of the tie between the mother and father, their relationships with relatives, friends, or neighbors, or their status in the local community or society (Schoen et al. 1997, Hoffman and Hoffman 1973). Moreover, as individuals build their social networks within their spheres of living (Feld 1981), children change the social circles of their parents. Playgrounds, kindergartens, or schools provide access to people whom they probably would not have met otherwise.

These changes are closely associated with the provision of child-related benefits. As individuals intend to profit form their activities, they start or maintain a relationship under the expectation of gaining utility from it (Coleman 1990). This implies that individuals are motivated to spend resources on this relationship to secure access to the benefits provided by the relationship partner. As both partners pursue the same motivation, a process of mutual exchange emerges. Thus, interpersonal relationships are constituted and characterized by the reciprocal exchange of, for example, information, goods, services, emotions, affection, or recognition (Emerson 1976, 
Mitchell 1973). Reciprocity means that the goods, services, emotions etc. that an individual receives from his or her network partners are of equal value compared to the goods, services, or emotions he or she gave to one or more individuals in his or her personal network. Reciprocity can be established in a direct or generalized manner, i.e., between two individuals or within a group (Ekeh 1974). It can be set up immediately or it can be postponed to a later or even unspecified period (Diewald 1991).

As reciprocal exchange is a universal element of interpersonal relationships, it is also present in family networks and the ties between the parents and their children (Schulz 1996, Ishii-Kuntz and Seccombe 1989, Nye 1979, Edwards 1969). Consequently, individuals decide to have a child, i.e., to give birth to a new network member and to establish a tie with him or her when they assume to profit from this relationship as well as from the child-induced changes in their relationships to other network members. These considerations lead to the following two conclusions. First, child-induced changes in the parents' networks cause the provision of childrelated benefits as these alter existing exchange processes or establish new ones. Second, there is a complementary association between exchange theory and the Theory of the Value of Children. Exchange theory proposes that individuals decide to have a child when they expect that the outcome of this decision alters their exchange relationships in a beneficiary way. The Theory of the Value of Children specifies the benefits that the individuals can gain due to particular alterations.

Parents profit from their children as direct exchange partners. The central aspects of the intrinsic and material values of children rest on the idea of direct exchange. In rearing, educating, or feeding a child, parents spend substantial amounts of time, money, energy, and mental resources in the expectation to receive love, affection, fun, satisfaction, support at old age, or material transfers from their children. Some of the intrinsic values, like fun, satisfaction, or aspects of self-enrichment and development, are primarily generated by the parents themselves. However, they would not arise without a relationship of interaction and exchange with the child. Moreover, due to the very close and highly emotional character of the tie between the parents and their children, parents are involved in exchange processes they would not experience in other relationships. One aspect is the postponement of reciprocity. Intergenerational transfers are characterized by long-term imbalances between the value of resources and efforts spent by the parents and the value of goods and services provided by the child. However, parents can benefit from this situation. They receive joy and satisfaction from observing how their transfers support their child in growing and flourishing (Becker 1993) and they create an insurance value, as the child feels obliged to establish reciprocity in the long run by supporting its parents in the cases of illness or accidents or by taking care of them when they are old (Nauck 2005).

The birth of a child also induces changes in parents' exchange processes with family members. There are, on the one hand, the intergenerational relationships between the child's parents and its grandparents. The grandparents can become motivated to establish a closer relation- 
ship with their grandchild and its parents and to support the growing family. In addition, parents can benefit from their relationships with other family members and kin. Due to their ascribed nature, these relationships enable the generation of stable systems of interpersonal exchange, characterized by norms of reciprocity and the commitment of mutual assistance (Gouldner 1960). Therefore, family members feel obliged to support the growing family and the parents do not have to repay the members immediately for the assistance they received.

Finally, children are beneficial by changing the position and the roles of the parents in the local community. In traditional societies, the situation of parenthood or of being a mother or father of a large family changes the recognition and evaluation of the parents by the social environment. The new status may provide parents with power in the family or local community or with a social or economic advantage due to an increase in the prestige of the mother and/or father (Hoffman and Hoffman 1973). In many cases, children are one of the parents' scarce opportunities to invest in their own economic well-being or to increase their power and influence. Parents and their families also gain advantages through their children's marriages as these strengthen the parental status as well and create new opportunities for interpersonal exchange with the members of the family-in-law or with members of the local community (Levi-Strauss 1993). It is questionable, however, to what extent these considerations apply to modern societies. Here, the advantageous status of parenthood is very much legally defined, as it gives parents and their children access to transfer payments, social insurance services, or tax advantages.

According to the arguments presented above, important aspects of the provision of childrelated benefits rest on alterations in parents' personal networks and exchange relationships that are induced by the birth of a child. This circumstance can be summarized under the term 'structural value' of children to their parents. In referring to these structural attributes, the concept illustrates that parents' access to child-related advantages is not automatically given. Benefits that are directly provided by the child, but also the satisfaction of intrinsic values, depend among other things on the quality of the tie between the child and its parents. Child-induced benefits from the family or the social environment rest on network structures that create opportunities for parental status enhancement, the generation of prestige, growing influence, or increasing access to supportive resources. These opportunities are often the expressions of social or cultural evaluations of parenthood and family size as well as of gender-specific role models.

\subsubsection{The purposeful utilization of the structural value of children}

The structural value of children is not a new concept in the literature on fertility, although it was not addressed directly up to now. As previously argued, the great variety of values that are covered by the Theory of the Value of Children also considers benefits that emerge from structural changes in the parents' social relationships, like an increase of power or prestige. A more recent approach discusses the structural value of children more explicitly within the context of the ac- 
cumulations of the parents' social capital (Astone et al. 1999, Schoen et al. 1997). Following a network perspective, this approach perceives social capital as emerging from the goods and services an individual has access to through his or her personal relationships (Bourdieu 1983, Flap 2002, Lin 2001, Coleman 1990). This includes the parents' relationships with their children. Children contribute to their parents' social capital as they provide goods and services directly or as the child-induced changes of the parents' social networks give indirect access to resources located with other network members.

As social capital is located in interpersonal relationships and as it is accumulated by processes of reciprocal exchange (Bühler and Philipov 2005, Astone et al. 1999, Coleman 1990, Bourdieu 1983), the theory of children as social capital rests on similar structural mechanisms as the structural value of children. The theory specifies, therefore, one part of the great variety of benefits that are provided by children. However, in focusing on the capital character of children, it addresses the situation that parents purposefully utilize their children as a means to alter the structures of their social networks in order to improve their access to resources. Consequently and more generally spoken, individuals can be aware of the structural value of children and the expectation of advantageous changes in their personal relationships and exchange processes can be a substantive argument in favor of having a child.

This conclusion helps to understand particular subjective evaluations as they are expressed by individuals when they are asked about the costs and benefits of a child. These evaluations are not associated with a concrete intrinsic or material profit, but with a general prospect of an improving social environment. Afro-American adolescents who live in precarious social circumstances report repeatedly about the expectation that having a child will stabilize their living situations and motivate members of their social networks to provide support (Geronimus 2003, Schoen and Tufis 2003, Friedman, Hechter, and Kanazawa 1994, McCue et al. 1991). Schoen et al. (1997) show that the perception of children as a means to improve one's personal relationships in various ways had a strong impact on the fertility motivations of American adults in the 1980s. Of course, individuals are hardly likely to evaluate the abstract changes in their social networks. They more probably consider the expected but unspecified benefits due to these changes. Thus, the structural value of children works to some extent as a summarizing evaluation. Individuals assume that their personal situation improves in general due to the child-induced changes in their personal relationships, but they can not specify these expected advantages in detail.

The subsequent empirical analyses will address the structural value of children in this context. They explore the extent to which individuals associate the birth of a child with a possible improvement of their social environments and the degree to which these evaluations have an impact on their intended fertility. To our knowledge, the significance of structural evaluations is up to now primarily documented with data from the U.S. However, results from different social and cultural settings are needed to learn more about the general importance of this kind of evaluation. 
The analyses focus on Bulgaria. This country has been chosen because of the availability of appropriate quantitative data and due to the fact that Bulgaria has a long tradition of active help and support between individuals and households, as do other Central and Eastern European countries (Sik 1995). This tradition matters for fertility-related decisions in Bulgaria as individuals' embeddedness in supportive personal relationships shows a positive impact on their willingness to have a first or a second child (Bühler and Philipov 2005, Philipov, Spéder, and Billari 2005). It is, therefore, of interest to see, whether social networks work only as a structural determinant of fertility intentions in Bulgaria or whether expected child-induced changes in these networks are an important motivation for reproduction as well.

\subsection{Fertility intentions}

The empirical analyses will investigate the significance of the structural value of children to individual fertility intentions. The focus on intended fertility except observed fertility is supported by two general arguments. Firstly, similar to values in general (Hitlin and Piliavin 2000, Schwartz 1994, Feather 1995), child-related evaluations stimulate behavior in a cognitive and motivational way, but they do not determine behavior directly. This motivational character identifies the position of values in the process of reproductive decision-making and behavior (Miller 1994, 1986, Miller and Pasta 1996, 1993). This process starts with fertility-related motivations that shape particular desires, which are again translated into reproductive intentions. Intentions mark the stage at which individuals decide about a reproductive goal and about the means to reach it. These decisions are transferred to proceptive or contraceptive activities that finally lead in dependence of situational forces to desired or undesired outcomes. Because motivations and desires influence fertility-related activities only indirectly via intentions, the process can analytically be summarized in two parts: an intentional one that covers the developments of the internal states of motivations, desires, and intentions, and a behavioral one that draws attention to the instrumental activities to realize an intended reproductive goal. Subjective evaluations of children form, besides biological and cultural dispositions as well as individual traits, a central aspect of the intentional part of this process (Miller 1995, Miller and Pasta 1993).

Secondly, the separation between fertility-related decision making and instrumental behavior helps to understand the observed levels of fertility as expressions of intentions and of situational forces, which hinder, slow down, or promote the pursuance of an intended reproductive goal (Bongaarts 2001, 1990, Morgan 2003, Quesnel-Vallée and Morgan 2003, Schoen et al. 1999). Consequently, knowledge about the determinants of intended fertility will help to improve the understanding of observed fertility and the significance of intervening situational forces in the process. 


\section{Data and variables}

\subsection{Data}

The empirical analyses use data from the first wave of the Bulgarian panel survey "The Impact of Social Capital and Coping Strategies on Reproductive and Marital Behavior", which is carried out under the responsibility of the Max Planck Institute for Demographic Research and the Bulgarian Academy of Sciences. The first wave took place in summer 2002 and the second was realized in autumn 2005. As the study focuses on the events of leaving the parental home, marriage, and fertility, the survey's population is restricted to the age cohorts in which these events normally take place in Bulgaria. Thus, female respondents are aged between 18 and 34. Male respondents are in the same age range if they are unmarried and do not live together with a partner. The age range of married or cohabiting males is 18 to 66 . This is because the corresponding spouse or partner was automatically interviewed with each married or cohabiting female respondent. The sample was realized in collaboration with the Bulgarian National Statistical Office. Of the 10,009 individuals that were successfully interviewed, 5,765 were married or cohabiting and 4,244 were single, divorced, or widowed at the time of the interview.

A sub-population of the respondents will subsequently be considered. Ethnic Turks and Roma form a substantive part of the Bulgarian population. Turkish and Roma respondents thus represent $9.7 \%$ and $7.1 \%$ of the realized sample, respectively. Explorative analyses have shown that fertility behavior and its determinants differ significantly between the respondents with a Turkish, Roma, and Bulgarian ethnic background. It also turned out that the differences can not be covered in full in multivariate analyses by variables that control for ethnicity. Analyses separated by ethnic groups would solve this problem, but they would reach beyond the scope of this paper. Therefore, 8,093 respondents of Bulgarian ethnicity are considered. This population is additionally limited to all 5,802 female and male respondents who have a partnership at the time of the interview, either by being married, living in cohabitation, or by having an intimate friend for at least three months. Intentions reflect the reality of individuals. Consequently, it is meaningful to consider only respondents for whom fertility is a topic and who might start concrete considerations about the pros and cons of having a child. This situation is broadly covered by the fact that a respondent has a partnership. Of course, interviewees without a partnership can evaluate the costs and benefits of a child, but they would give these evaluations on a much more hypothetical basis as do respondents with a partner. Finally, all of the respondents who know for sure to be infertile or who were pregnant or whose partner was pregnant at the time of the interview are not taken into account. Therefore, the subsequent analyses start with a population of 2,697 female respondents and 2,604 male respondents. 


\subsection{Fertility intentions}

Individuals formulate fertility-related intentions on the basis of their desires and under the consideration of environmental and situational circumstances. Consequently, intentions may change when the determining circumstances are changing. This does not mean that individuals completely alter their motivations and desires, but that they make new decisions and formulate new or modified intentions. Thus, information about long-term fertility intentions, i.e., whether an individual ever intends to have a first or another child, provides a general estimate for future quantum-related fertility, but its accuracy to predict individual reproductive behavior is limited. Fertility intentions that are related to a short time horizon, and that are subsequently used as depend variables, promise to reflect reproductive decisions in a more reliable way (Billari and Philipov 2005).

In the questionnaire, these short-term intentions were covered by the question of whether a respondent "intends to have a first or another child within the next two years". Respondents could choose between the answer categories "definitely yes", "probably yes", "probably not", and "definitely not" (see Table 1 for descriptions of the variables used in the analyses). Due to the ordinal character of this variable, the subsequent multivariate analyses are performed by ordinal logit regressions.

\section{TABLE 1 ABOUT HERE}

\subsection{Subjectively expected costs and benefits of children}

The costs and benefits of children were addressed against the background of the theory of Purposeful Behavior in order to measure the respondents' attitudes of having a first or another child (see Billari and Philipov 2005). The related questions mentioned a variety of basic child-related costs and benefits, but they neither systematically covered all dimensions of positive and negative incentives as they are embraced by the Theory of the Value of Children nor were they explicitly developed in order to test the structural value of children. However, some questions provide information about structural child-related evaluations.

The attitudes were measured by confronting the respondents with a hypothetical situation: "If you would have a child during the next two years, irrespective of whether you really wish to have a child or not, to what extent do you agree that this would ...?" Then the interviewer read out a statement that mentioned a particular child-related cost or benefit and the respondent was asked to evaluate this statement by expressing his or her degree of agreement or disagreement (see Appendix A for a documentation of the statements used in the questionnaire). Three statements cover aspects of the structural value of children: an expected increase in closeness with the partner, growing closeness with parents and relatives, and greater security at old age. The first two statements focus on the structural value of children directly by mentioning possible 
improvements of relationships. It is assumed that the respondents do not perceive a closer relationship as a value in itself, but as a summarizing evaluation of the expected benefits provided by the closer relationship. The value of old age security addresses the child as a direct source of resources, which is an expression of the direct exchange relationship between the parents and the child.

The analyses will highlight the results for these three statements. However, to evaluate their importance to fertility intentions, other values and a variety of costs need to be considered as well. The additional values include the prospect of greater joy and satisfaction in daily life and the continuation of a part of the respondent into the future. The statements about costs address economic difficulties arising from the birth of a child, negative consequences for a respondent's working career and/or higher education, more worries and preoccupations in the course of daily life, and reduced time for personal interests or contacts to friends. The latter statement considers the possibility that children can also deteriorate individuals' social networks. In spending substantive amounts of time and energy in rearing and brining up a child, individuals are less able to maintain their personal relationships to other network partners, like friends. This may reduce the heterogeneity of resources available in the parents' social networks as friends are closely associated with the provision of information, emotional support, or sociability. Finally, the female respondents were additionally asked how much a child would increase their physical burden due to its birth, care, or breastfeeding. ${ }^{1}$

The respondents' evaluations of child-related costs and benefits are measured on an ordinal scale, which is considered in the subsequent descriptive analyses. However, due to the skewed distributions of respondents' agreements or disagreements to a variety of statements (see Table 1), the evaluations enter the multivariate analyses only by one dummy variable. This variable covers all respondents that completely or rather agreed to a particular statement. The reference category consists of all respondents who "neither agreed nor disagreed", "rather disagreed", or "completely disagreed".

\subsection{Control variables}

Primarily for purposes of control, the multivariate analyses consider some basic characteristics of the respondents and their households. The age of the female respondents is represented by two dummy variables, denoting ages 18 to 25 or 26 to 30 . Women aged between 31 and 34 build the reference category. The age of the male respondents is represented by the same dummy variables

\footnotetext{
${ }^{1}$ The analyses do not consider the statements that address an increase or decrease of uncertainty due to the birth of a child (see Appendix A). According to Friedman, Hechter, and Kanazawa (1995), the reduction of uncertainty is one general immanent value that individuals intend to fulfill. However, these general values cannot be approached directly (Lindenberg 1990, Esser 1996). Individuals have to translate them into context-specific goals and evaluations. Consequently, the presence of general values can be measured by context-specific statements, but not by statements that address them directly and in an abstract manner.
} 
plus a third one, which gives information about whether the respondent is aged between 31 and 35. All males that are 36 to 66 years old build the reference category. A metric variable represents the number of siblings that a respondent has. Two dummy variables provide information whether the respondent has gained a tertiary education and whether he or she intends to start education within the next two years. The fact that the respondent received an income from labor during the last three months before the interview is represented in the same way. A further dummy variable reports about the respondent's degree of self-evaluated religiousness, i.e., whether he or she calls himself or herself 'a religious person'. Two variables characterize a respondent's household: the logarithm of its equivalence income, expressed by the household members' per capita income weighted by the age structure of the household, ${ }^{2}$ and a dummy variable that controls for differences in fertility intentions between urban and rural areas.

\section{Empirical results}

The empirical results are presented in two steps. First, distributions of fertility intentions and expected costs and benefits are discussed in order to receive an impression of the respondents' general willingness to have a first or another child within the next two years and to assess the relevance of the structural value of children in comparison to alternative values and opposing costs. The results are presented separately by gender, kind of partnership, and parity. Separation by the kind of partnership is made owing to the assumption that the respondents with an intimate friend face different living situations than respondents who live together with a partner, either married or in cohabitation. As most of the respondents with an intimate friend are childless, the analyses consider only this group. ${ }^{3}$

\subsection{Fertility intentions}

Before the breakdown of Socialism in 1989, fertility in Bulgaria was characterized by almost universal parenthood, high rates of two-child families, and a stable fertility rate around replacement level (Shkolnikov et al. 2004). These characteristics changed significantly during the transition period. The Total Fertility Rate declined from 1.90 in 1989 to 1.09 in 1997 and increased slightly to a level of 1.29 in 2004 (Max Planck Institute for Demographic Research 2006). Twochild families became less present and the overall decline of fertility was very much caused by a

\footnotetext{
${ }^{2}$ Information about a household's income is covered by an ordinally scaled variable with the following categories: 'up to $100 \mathrm{Leva}$ ', '101 to $200 \mathrm{Leva}$ ', '201 to $300 \mathrm{Leva}$ ', '301 to $400 \mathrm{Leva}$ ', '401 to 600 Leva', '601 to $800 \mathrm{Leva}$ ', '801 to 1,000 Leva', and '1,001 Leva or more'. To calculate the equivalence income, the value of the center of each income interval is taken. As to the highest income category, a value of 1,200 Leva is set. The household size is weighted according to the modified OECD scale (Dennis and Guio 2004). The first adult is weighted with the factor 1.0. Every additional household member who is older than 13 years receives a weight of 0.5 . If he or she is aged 13 or younger, a weight of 0.3 is set.

${ }^{3}$ Among the female respondents with an intimate friend, 49 individuals have one child, seven have two children, and one person has three or more children. The group of male respondents with an intimate
} 
significant reduction of second order births (Philipov and Kohler 2001, Spielauer 2005). However, the aspect of almost universal parenthood remained, i.e., living in a partnership, either married or in cohabitation, is directly associated with having at least one child.

The intentions of female and male respondents to have a first or another child within the next two years reflect to some extend these developments (see Tables $2 \mathrm{a}$ and $2 \mathrm{~b}$ ). Around two thirds of the childless female (66.5\%) and male $(67.1 \%)$ respondents who are married or cohabiting definitely or probably want to have a first child within the next two years. However, this intention significantly declines with parity. Only around one third of the female and male respondents with one child (35.6\% and 39.5\% respectively) aspires to have a second child within a twoyear period and there is only a minority among the respondents with two or more children that intends to have an additional child.

Becoming a mother or father is not a serious perspective for most of the respondents with an intimate friend. Among the female and male respondents, $65.0 \%$ and $75.7 \%$ probably or definitely do not want to pursue this aim within the next two years. Consequently, reproductive planning is closely associated with a stable partnership and a socially accepted way of living together, either in a marriage or cohabitation.

\section{TABLE 2 ABOUT HERE}

The results in the Tables $2 \mathrm{a}$ and $2 \mathrm{~b}$ have consequences for the subsequent multivariate analyses. As the overall number of married or cohabiting respondents with three or more children is too small and as the distributions of female and male respondents with two children are too skewed, the estimates will concentrate on the groups of married or cohabiting respondents who are childless or who have one child and on the group of childless respondents with an intimate friend.

\subsection{The perceived benefits of children}

Figures 1 and 2 report the distributions of the respondents' agreements and disagreements to the statements addressing the different benefits and costs of having children. The results are presented for the same groups of respondents as in Table 2.

The first part of Figure 1 documents the replies to the statements that cover aspects of the structural value of children. Consistent with results from other studies (Bulatao 1981, Fawcett 1988), married or cohabiting interviewees especially associate the birth of a first child with the expectation of greater closeness with the partner. Among the childless female and male respondents, $76.4 \%$ and $84.9 \%$ completely or rather agree with the related statement in the questionnaire (see Appendix B.1 for percentages and case numbers). The share of positive evaluations decreases with parity, but more than $40 \%$ of the male and female respondents with three or more 
children still associate the birth of another child with an improvement in their relationships with their partners. Many respondents also express the prospect that a first child would bring their parents and relatives closer (66.4\% and $71.7 \%$ of the childless female and male respondents). A similar result holds for security at old age. Of the childless female and childless male respondents, $53.7 \%$ and $63.2 \%$ completely or rather agree with this statement. However, as the share of agreement is continuously declining with parity, the results do not support insights from other countries where the expectation of old age security is primarily associated with children of high parity (Bulatao 1981).

Altogether, the distributions of male and female respondents in the first part of Figure 1 show that married or cohabiting males tend to suppose more often than do females an improvement in their social environments due to the birth of a child. This holds especially for the expectations that are associated with a second or third child.

\section{FIGURE 1 ABOUT HERE}

Although many respondents link the birth of a child to improvements in the social environment, a much higher share expects to profit in the form of greater joy and satisfaction in daily life and/or the continuation of one's part into the future. Among the childless female and male respondents, 91.5\% and 93.2\% completely or rather agree with the statement that a first child increases joy and satisfaction. This positive evaluation is consistently declining with parity, but it remains to be an important prospect. Especially female respondents express the prospect that a child would continue a part of them into the future. Depending on the number of children they already have, $80 \%$ to $90 \%$ completely or rather agree with this statement.

The evaluations by the respondents with an intimate friend of having a first child are similar to the replies of married or cohabiting interviewees. However, there are some exceptions. The male respondents with an intimate friend expect significantly less often greater old age security or more joy and satisfaction in their life. The female respondents with an intimate friend perceive significantly more often the benefit, that a first child would continue a part of them into the future.

\subsection{The perceived costs of children}

Figure 2 reports the distributions of agreements and disagreements related to the statements that address the different expected costs of children. Most of the married or cohabiting female and male respondents completely or rather agree that a first or another child would increase their economic difficulties. Especially women link this cost with the number of children they already have. Of the female respondents, $75.3 \%$ of those who are childless but $90.5 \%$ of those who have three or more children completely or rather agree with the related statement (see Appendix B.2 
for percentages and case numbers). Moreover, the high share of women who definitely suppose rising economic difficulties is remarkable. The considerations that a first or another child increases the respondent's worries and preoccupations in their daily life show a similar pattern. The majority of female and male respondents shares this perception and especially women assume a growth in this cost with rising parity.

The distributions of the respondents' evaluations that a first or another child will reduce the time available for personal interests and contacts with friends document some gender-specific patterns. Around the same share of childless women $(69.9 \%)$ and men $(65.6 \%)$ completely or rather agrees with the related statement. With increasing parity, however, the share of agreeing women rises slightly, whereas the share of agreeing males declines. Thus, especially women expect to face a potential devaluation of their networks due to the birth a child.

\section{FIGURE 2 ABOUT HERE}

Gender-specific opportunity costs can also be observed in the context of decreasing chances in the employment career and/or in tertiary education. Independent of parity, female respondents much more often completely or rather agree with the related statement than do male respondents. For example, $47.5 \%$ of the childless female respondents assume a narrowing in their career opportunities due to the birth of a first child, but only $16.2 \%$ of the childless male respondents do so. However, another high portion of women does not perceive this kind of cost. Among the female respondents who are childless or who have one child, $44.8 \%$ and $38.7 \%$ completely or rather disagree with the statement. These results may reflect different biographical perspectives. A share of women experiences the birth of a first or second child as a competitive situation between the family and their occupational intentions. Other women, however, tend to be more family-oriented and do not suppose an increase in their opportunity costs. Finally, Figure 2 shows that more women expect the more physical burdens due to the birth of another child, child care, or breast feeding, the more children they already have.

In general, male respondents' expectations are less often associated with an increase in child-related costs (see Beckman 1987 for a similar result). This does not only hold for an expected narrowing in working career and/or higher education, but also for daily life worries and preoccupations, or less time for personal interests and contacts with friends.

Childless respondents with an intimate friend assume more often increasing costs due to the birth of a first child than do childless married or cohabiting respondents. This holds especially for male respondents, but for female respondents as well within the context of decreasing time for personal interests and decreasing chances in the working career and/or higher education. 


\subsection{Multivariate Analyses}

According to the results of the descriptive analyses, a large number of respondents expects that the birth of a first or second child improves their social environments. However, do these prospects promote the respondents' intentions to have a child within the next two years? The subsequent multivariate analyses, reported in Tables 3 and 4, aim to provide an answer to this question. Table 3 lists the estimates for married or cohabiting female and male respondents. Table 4 presents the results for the respondents with an intimate friend. ${ }^{4}$

Although high shares of childless female and male respondents associate the birth of a first child with the expectation of increasing closeness with the partner or with their parents and relatives, only the latter evaluation supports their intentions to have this child within a two years period. Especially women associate a first child with the opportunity to improve their relationships with their family members and to bind their parents and relatives closer to their own families. Males' intentions tend to profit from this perception as well, although the influence is not significant. However, their willingness is significantly increasing when they evaluate a first child as a means to improve their security at old age. All other child-related benefits show nonsignificant effects for female and male respondents.

Among the expected costs, rising economic difficulties is a serious argument for female respondents not to have a first child soon. This does not imply that these women intend to stay childless. Given that most marriages and cohabitations in Bulgaria are associated with the birth of at least one child, this negative effect addresses intentions of postponement. However, this is not the case for male respondents. Although a high share of them associates the birth of a first child with growing economic difficulties, this evaluation does not have any influence on their intentions. Possible negative impacts on working careers and/or higher education are significant factors both for female and male respondents to have a first child in three years or later. Thus, respondents who perceive a challenging constellation between parenthood and their educational or occupational situation want to give priority to their occupational career and intend to have their first child at a suitable moment. Finally, women's evaluation that a first child will increase their physical burden shows an unexpected result. Female respondents who assume this kind of cost are significantly more often willing to give birth to a first child within the next two years than women who do not anticipate this load. Thus, the intention for a first child is closely associated with women's perceptions about the physical consequences of this decision and their willingness to take them.

According to the respondents' intentions to have a second child, the variables that represent aspects of the structural value of children document again gender-specific effects. Contrary

\footnotetext{
${ }^{4}$ Subsequently, only the effects of the subjectively expected benefits and costs of children are interpreted. The characteristics of the respondent and his or her household are only used for purposes of control. See Philipov et al. (2005) for a discussion of the influences of socio-economic characteristics on the respondents' fertility intentions.
} 
to childless respondents, the expectation that a second child will bring the partner closer is now a serious argument for female respondents to have this child within the next two years. However, the prospect of improving relationships with parents and relatives does not have any influence. For male respondents, a possible increase of security at old age due to a second child tends to be a reason to have this child, although this effect is not significant. The results also show that the intention for a second child is significantly promoted by the expectation that a growing family will increase joy and satisfaction. This applies both to female and male respondents.

Looking at the effects of the expected costs, the estimates show that the prospect of a worsening economic situation due to a second child is a serious argument to postpone the birth of this child or to stop childbearing. These results support insights from other studies that document the high sensitivity between the respondents' intentions to have a second child and their objective economic situations (Bühler 2005, Bühler and Philipov 2005, Philipov, Spéder, and Billari 2005). Especially for male respondents, potential child-related opportunity costs in their private and occupational sphere reduce their willingness to have a second child soon. The negative effects of the expectations of decreasing time for personal interests and contacts with friends and decreasing career opportunities document this conclusion. Contrary to the results for childless female respondents, women who assume that a second child increases their physical burdens are now significantly more often intending not to have this child within the next two years than women who do not assume to have this load. This result possibly reflects experiences made from giving first childbirth but it probably also addresses women's planning to have a second child when the first child becomes older and taking care of it becomes less work intensive.

\section{TABLE 3 ABOUT HERE}

The results for the group of childless respondents with a serious intimate friend report a different pattern of influential benefits and costs (see Table 4). For both female and male respondents, the expectation that a first child will bring the partner closer significantly promotes their intentions to have this child within the next two years. Thus, individuals who do not live together in a legally defined or socially accepted institution of marriage or cohabitation evaluate the binding force of a first child much more seriously as married or cohabiting respondents. This different living situation is additionally reflected by the fact that, contrary to the results in Table 3, increasing closeness with parents and relatives does not show an impact for female respondents and tends to have a negative influence for male respondents. However, similar to the results for married or cohabiting males, the intentions of male respondents are significantly promoted by the prospect of increasing joy and satisfaction in their life, but they are significantly reduced by the evaluation that the first child will continue a part of them into the future. 
The high sensitivity of female respondents according to an expected growth of economic difficulties due to a first child applies also to the group of childless female respondents with an intimate friend. Women who perceive this kind of cost intend to postpone this child. Moreover, the expectation of increasing worries and preoccupations promote postponement as well. For male respondents, none of the assumed costs shows any influence on their intended fertility. Finally, the intentions of women with an intimate friend to have a first child within the next two years are promoted by their expectations of increasing physical burdens.

\section{Concluding discussion}

The purpose of the previous explanations was to discuss the structural value of children under a theoretical and empirical perspective. The theoretical section introduced the concept by arguing that substantive aspects of the value of children rest on interpersonal relationships between the parents and their children as well as between the parents and their relatives or other members of their social networks. Parents are provided with child-related benefits on the basis of changing processes of interpersonal exchange that characterize these relationships. Children are direct exchange partners of their parents and supply them with a variety of intrinsic and material benefits. Moreover, in reacting to the birth of a first or another child, relatives or other members of the social environment cause changes in the parents' status, prestige, power, or social recognition; these give them access to resources and advantages they did not have before. Therefore, children have a structural value to their parents as their birth induces direct and indirect changes in the parents' social networks, which build the basis for the provision of child-related benefits.

However, does this structural view offer any progress for research on fertility? At least three answers can be provided. First, by addressing the structural preconditions of the value of children, the concept emphasizes that child-related benefits are not automatically given. The direct provision of benefits through the child depends, among other things, on the quality and character of the relationship between the child and its parents, on the values and goals the parents pursue by having a child, as these determine the resources that the parents are willing to spend on the child, as well as on general role models of parents and children. Moreover, the parents' increase in status, power, or access to resources due to the birth of a child rests on opportunities offered by the social environment. These opportunities reflect cultural or social evaluations of parenthood or ideas of an appropriate family size. Thus, the structural value of children enables the identification of general meanings and implications of fertility by the characteristics of the parents' relationships with their children and the reactions of the larger family or the local community on parenthood.

Second, the concept links the value of children with other theoretical approaches. The perception of the relationships between the parents and their children as processes of reciprocal exchange brings together child-related values with theories of intergenerational transfers. The 
aspect of postponed reciprocity highlights the mechanism behind the way in which parents are able to ensure the provision of long-term or future advantages. Moreover, as exchange relationships are characterized by exchanges of heterogeneous material and non-material goods, the concept covers altruistic as well as instrumental motivations of the parents to transfer resources to their children. There are also overlaps with network-based theories of social capital. As these theories perceive the accumulation of individual social capital as an outcome of interpersonal exchange processes, they address the same structural mechanisms as does the structural value of children. Thus, the direct or indirect material benefits of children can form a substantive part of the parents' social capital. Social capital can be built up purposefully and parents can perceive children as a means for its accumulation. This leads to the general conclusion that parents can intend to have a first or another child in order to improve their social networks by deliberately forming the structural conditions for the provision of child-related benefits.

Third, by following the conclusion above, the concept of the structural value of children helps to understand the empirical phenomenon that individuals evaluate the birth of a child in terms of its potential to change their social environments in an advantageous way. Of course, individuals hardly evaluate the abstract changes in their social networks. They have more probably the expected outcome of these changes in mind. In this case, however, structural evaluations work as summarizing assessments, i.e., individuals suppose to profit from the birth of a child without being able to address these benefits in detail.

The empirical part studied the structural value of children under this perspective. It explored the expectations of Bulgarian females and males that children will improve their social environments and analyzed the implications of these prospects on their intentions to have a child within a two years period. Similar to results from the U.S. (Schoen and Tufis 2003, Schoen et al. 1997) estimates from multivariate analyses show that structural evaluations are significant motivations for having a first or second child. However, their influence varies with parity, gender, and marital status. Among the respondents who are married or live in cohabitation, women's intentions to have a first child are significantly promoted by the expectation of getting their parents and relatives closer. Moreover, their motivation for a second child within a two years period benefits from the prospect of a closer relationship with the partner. For male respondents, the perspective that a child will improve their security at old age is a significant argument to have a first child and it also tends to support their willingness for a second child. The intentions of female and male respondents with an intimate friend are significantly promoted by the expectation that this child will bring the partner closer. The intentions of male respondents with an intimate friend are additionally supported by an assumed increase of old age security.

The results give some hints that the significance of structural evaluations depends, among other things, on the respondents' living situations. Since most Bulgarian females and males get their first child at the beginning of their marriage or cohabitation, they do not have the 
need to utilize a child as a means to improve or strengthen the relationship with the partner. This does not apply to individuals with an intimate friend. Their relationships are not institutionalized and, therefore, they are less secure, also in its evaluation by the social environment. This may lead to the perception that a first child is an investment in the relationship as it has a high potential to strengthen the bond between the partners. Married or cohabiting couples, however, are more likely to have the need to receive material and non-material support from their relatives, to establish their family, and to integrate it in the wider context of kin and relatives. The significant sensitivity of male respondents that a first child will increase their security at old age refers to the fact that intergenerational transfers tend to have the character of long-term exchange processes in Bulgaria. Many parents expect to receive support from their children when they are old and many children feel obliged to balance the costs and efforts their parents have spent for them during their childhood. This perception is especially present among the male respondents and it promotes their intentions for a first child in a significant way.

Both the theoretical argumentation and the empirical analyses have to face shortcomings. One central idea of the structural value of children is that individuals do not perceive an improvement in their social environment as a value in itself, but as an expression of individual child-related benefits that become available due to the child-induced changes in their social networks. However, these benefits stand on a weak theoretical ground. Most of them are inductively generated from empirical research and do not rest on deductive derivations from theory (Nauck 2005, Friedman, Hechter, and Kanazawa 1994). Up to now, this criticism has not been considered intensively in research on fertility. One way to solve this difficulty is the derivation of childrelated benefits from the general immanent values all people struggle to fulfill (Nauck 2005, Friedman, Hechter, and Kanazawa 1994, Lindenberg 1990, 1991). In this case, the evaluations of children and the related benefits are expressions of these general values, which individuals intend to accomplish in the living-sphere of their families.

The empirical analyses face the problem that the instruments used to measure the structural value of children and their impacts on fertility intentions have an ad hoc character. Although the utilization of child-related attitudes to measure child-related values is methodologically meaningful, the statements that address the structural value of children did not emerge from systematic theoretical considerations. Moreover, the statements do not directly address children as a means to improve the respondents' social environments. Thus, an improved empirical examination of the structural value of children needs a more theory-driven measurement. This would particularly enable a direct and critical examination of the two central hypothesis of the concept: individuals evaluate children as a means to improve their social networks and structural evaluations reflect the expected provision of particular but unspecified benefits. 


\section{Literature}

Arnold, Fred, Rodolfo A. Bulatao, Chalio Buripakdi, Betty Jamie Chung, James T. Fawcett, Toshio Iritami, Sung Jin Lee, and Tsong-Shien Wu. (1975). The Value of Children. A Cross-National Study. Volume One: Introduction and Comparative Analysis. Honolulu: East-West Center, East-West Population Institute.

Astone, Nan Marie, Constance A. Nathanson, Robert Schoen, and Young J. Kim. (1999). "Family Demography, Social Theory, and Investment in Social Capital." Population and Development Review, 25, 1: 1-31.

Becker, Gary S. (1993). A Treatise of the Family. Cambridge: Harvard University Press.

Beckman, Linda J. (1987). "Changes in Motivation for Parenthood Among Young Married Couples." Population and Environment, 9, 2: 96-110.

Bernardi, Laura. (2003). "Channels of Social Influence on Reproduction." Population Research and Policy Review, 22: 527-555.

Bernardi, Laura, Holger von der Lippe, and Sylvia Keim. (2005). Mapping Social Influence on Fertility: A Mixed Method Approach to Data Collection. MPIDR Working Paper WP-2005-015, Max Planck Institute for Demographic Research, Rostock.

Billari, Francesco C. and Dimiter Philipov. (2005). The Influence of Attitudes, Subjective Norms and Perceived Behavioral Control on Fertility Intentions. Paper presented at the Annual Meeting of the Population Association of America, Philadelphia, April 2005.

Bongaarts, John. (2001). "Fertility and Reproductive Preferences in Post-Transitional Societies." Population and Development Review, 27: S260-S281.

Bongaarts, John. (1990). "The Measurement of Wanted Fertility." Population and Development Review, 16, 3: 487-506.

Bourdieu, Pierre. (1983). Ökonomisches Kapital, kulturelles Kapital, soziales Kapital. In: Reinhard Kreckel, editor. Soziale Ungleichheiten. Soziale Welt Sonderband 2. Göttingen: Schwarz: 183-198.

Bühler, Christoph. (2005). How Much do Inequalities of Income Matter for Fertility Intentions in Transitional Societies? Some Empirical Descriptions from Bulgaria. Paper presented at the Annual Meeting of the Population Association of America, Philadelphia, April 2005.

Bühler, Christoph and Ewa Fratczak. (2005). Learning from Others and Receiving Support: The Impact of Personal Networks on Fertility Intentions in Poland. MPIDR Working Paper WP-2005-017, Max Planck Institute for Demographic Research, Rostock.

Bühler, Christoph and Dimiter Philipov. (2005). "Social Capital Related to Fertility: Theoretical Foundation and Empirical Evidence from Bulgaria." Vienna Yearbook of Population Research, 2005: 53-81.

Bühler, Cristoph and Hans-Peter Kohler. (2004). „Der Einfluss starker Beziehungen auf die Nutzung moderner Kontrazeptiva."Zeitschrift für Soziologie, 33, 1: 5-25.

Bulatao, Rodolfo A. (1981). "Values and Disvalues of Children in Successive Childbearing Decisions." Demography, 18, 1: 1-25.

Bulatao, Rodolfo A. and Fred Arnold. (1977). Relationships between the Value and Cost of Children and Fertility: Cross Cultural Evidence. Reprint No. 92, East-West Center, East-West Population Institute, Honolulu.

Burt, Ronald S. (1982). Toward a Structural Theory of Action. Network Models of Social Structure, Perception, and Action. New York: Academic Press.

Casterline, John B. (2001): Diffusion Processes and Fertility Transition: Introduction. In: John B. Casterline, editor. Diffusion Processes and Fertility Transition. Selected Perspectives. National Research Council, Division of Behavioral and Social Sciences and Education, Committee on Population, Washington, D.C.: National Academy Press: 1-38.

Coleman, James S. (1990). Foundations of Social Theory. Harvard: Harvard University Press. 
Dennis, Ian and Anna Catherine Guio. (2004). „Monetäre Armut in den Neuen Mitgliedsstaaten und den Bewerberländern." Statistik kurz gefasst: Bevölkerung und soziale Bedingungen, 12/2000. Luxembourg: Eurostat.

Diewald, Martin. (1991). Soziale Beziehungen: Verlust oder Liberalisierung? Soziale Unterstützung in informellen Netzwerken. Berlin: Edition Sigma.

Edwards, John N. (1969). "Familial Behavior as Social Exchange." Journal of Marriage and the Family, 31, 3: 518-526.

Ekeh Peter. (1974). Social Exchange Theory: The Two Traditions. Cambridge: Harvard University Press.

Emerson, Richard M. (1976). "Social Exchange Theory.” Annual Review of Sociology, 2: 335362.

Esser, Hartmut. (1996). „Die Definition der Situation“. Kölner Zeitschrift für Soziologie und Sozialpsychologie, 48: 1-34.

Fawcett, James T. (1988). "The Value of Children and the Transition to Parenthood." Marriage and Family Review, 12, 3-4: 11-34.

Fawcett, James T. (1978). The Value and Cost of Children: Converging Theory and Research. Reprint No. 108, East-West Center, East-West Population Institute, Honolulu.

Feather, N. T. (1995). "Values, Valances, and Choice: The Influence of Values on the Perceived Attractiveness and Choice of Alternatives." Journal of Personality and Social Psychology, 68, 6: 1135-1151.

Feld, Scott L. (1981). "The Focused Organization of Social Ties." American Journal of Sociology, 86: 1015-1035.

Flap, Henk. (2002). No Man is an Island. In: Olivier Favereau and Emanuel Lazega, editors. Conventions and Structures in Economic Organization: Markets, Networks and Hierarchies. London: Edward Elgar: 29-59.

Fischer, Claude S. (1982). To Dwell Among Friends. Personal Networks in Town and City. Chicago: Chicago University Press.

Friedman, Debra, Michael Hechter, and Satoshi Kanazawa. (1994). "A Theory of the Value of Children." Demography, 31, 3: 375-401.

Geronimus, Arline T. (2003). "Damned if You Do: Culture, Identity, and Teenage Childbearing in the United States." Social Science \& Medicine, 57: 881-893.

Gouldner, Alvin W. (1960). "The Norm of Reciprocity. A Preliminary Statement". American Sociological Review, 25: 161-178.

Haug, Sonja. (2000). Soziales Kapital und Kettenmigration. Italienische Migranten in Deutschland. Opladen: Leske + Budrich.

Hitlin, Steven and Jane Allyn Piliavin. (2004). "Values: Reviving a Dormant Concept." Annual Review of Sociology, 30: 359-393.

Hoffman, Lois Wladis. (1987). "The Value of Children to Parents and Childbearing Patterns." Social Behaviour, 2: 123-141.

Hoffman, Lois Wladis and Martin L. Hoffman. (1973). The Value of Children to Parents. In: James T. Fawcett, editor. Psychological Perspectives on Population. New York: Basic Books: 19-76.

Hoffman, Lois Wladis and Jean Denby Manis. (1979). "The Value of Children in the United States: A New Approach to the Study of Fertility." Journal of Marriage and the Family, 41, 3: 583-596.

Hollerbach, Paula E. (1983). "Fertility Decision-Making Processes: A Critical Essay." In: Rodolfo A. Bulatao and Ronald D. Lee, editors. Determinants of Fertility in Developing Countries. Volume 2, New York et al.: Academic Press: 340-380.

Hurlbert, Jeanne and Alan C. Acock. (1990). "The Effects of Marital Status on the Form and Composition of Social Networks." Social Science Quarterly, 71: 163-174. 
Ishii-Kuntz, Masako and Karen Seccombe. (1989). "The Impact of Children upon Social Support Networks throughout the Life Course." Journal of Marriage and the Family, 51, 3: 777-790.

Kohler, Hans-Peter. (2001). Fertility and Social Interactions: An Economic Perspective. Oxford: Oxford University Press.

Kohler, Hans-Peter, Jere R. Behrman, and Susan C. Watkins. (2001). "The Structure of Social Networks and Fertility Decisions: Evidence from South Nyanza District Kenya." Demography, 38: 43-58.

Lévi-Strauss, Claude. (1993[1949]). Die elementaren Strukturen der Verwandtschaft. Frankfurt/Main: Suhrkamp.

Leydesdorff, Loet. (1991). "The Static and Dynamic Analysis of Network Data Using Information Theory." Social Networks, 13: 301-345.

Lin, Nan. (2001). Social Capital. A Theory of Social Structure and Action. Cambridge: Cambridge University Press.

Lindenberg, Siegwart. (1991). Social Approval, Fertility and Female Labour Market. In: Jaques J. Siegers, Jenny de Jong-Gierveld, and Evert van Imhoff, editors. Female Labour Market Behaviour and Fertility. Berlin et al.: Springer: 32-58.

Lindenberg, Siegwart. (1990). Rationalität und Kultur. Die verhaltenstheoretische Basis des Einflusses von Kultur auf Transaktionen. In: Hans Haferkamp, editor. Sozialstruktur und Kultur. Frankfurt/Main: Suhrkamp: 249-287.

Max Planck Institute for Demographic Research. (2006). Generations and Gender Contextual Database. Beta Version. Rostock.

McCue, Horwitz, Sarah Lorraine V. Klerman, H. Sung Kuo, and James F. Jekel. (1991). "Intergenerational Transmission of School-Age Parenthood." Family Planning Perspectives, 23: 168-172+177.

Miller Warren B. (1995). "Childbearing Motivation and its Measurement." Journal of Biosocial Science, 27: 473-487.

Miller, Warren B. (1994). "Childbearing Motivations, Desires, and Intentions: A Theoretical Framework." Genetic, Social, and General Psychology Monographs, 102, 2: 223-258.

Miller, Warren B. (1986). "Proception: An Important Fertility Behavior." Demography, 23, 4: 579-594.

Miller, Warren B. and David J. Pasta. (1996). "Couple Disagreement: Effects on the Formation and Implementation of Fertility Decisions." Personal Relationships, 3: 307-336.

Miller, Warren B. and David J. Pasta. (1993). "Motivational and Nonmotivational Determinants of Child-Number Desires." Population and Environment, 15, 2: 113-138.

Mitchell, J. Clyde. (1973). Networks, Norms, and Institutions. Jeremy Boissevain and J. Clyde Mitchell, editors. Social Networks in Urban Situations. Manchester: Manchester University Press: 1-50.

Montgomery, Mark R. and John B. Casterline. (1996). "Social Learning, Social Influence, and New Models of Fertility." Population and Development Review, 22: S151-S175.

Morgan, S. Philip. (2003). "Is Low Fertility a Twenty-First-Century Demographic Crisis?" Demography, 40, 4: 589-603.

Nauck, Bernhard. (2005). The Changing Value of Children - A Special Action Theory of Fertility Behavior and Intergenerational Relationships in Cross-Cultural Comparison. In: Wolfgang Friedlmeier, Pradeep Chakkarath, and Beate Schwarz, editors. Culture and Human Development. The Importance of Cross-Cultural Research to the Social Sciences. Hove and New York: Psychology Press: 183-202.

Nye, F. Ivan. (1979). Choice, Exchange, and the Family. In: Wesley R. Burr, Reuben Hill, F. Ivan Nye, and Ira L. Reiss, editors. Contemporary Theories about the Family. General Theories/Theoretical Considerations. New York: The Free Press: 1-41. 
Palloni, Alberto, Douglas S. Massey, Miguel Ceballos, Kristin Espinosa, and Michael Spittel. (2001). ,Social Capital and International Migration: A Test Using Information of Family Networks." American Journal of Sociology, 106: 1262-1298.

Philipov, Dimiter and Hans-Peter Kohler. (2002). Tempo Effects in the Fertility Decline in Eastern Europe: Evidence from Bulgaria, the Czech Republic, Hungary, Poland, and Russia. European Journal of Population, 17: 37-60.

Philipov, Dimiter, Zsolt Spéder, and Francesco C. Billari. (2005). Tempo and Quantum Fertility Intentions. A Study of Bulgaria and Hungary. Unpublished manuscript, Vienna Institute of Demography, Vienna.

Quesnel-Vallée, Amélie and S. Philip Morgan. (2003). "Missing the Target? Correspondence of Fertility Intentions and Behavior in the U.S." Population Research and Policy Review, 22: 497-525.

Schoen, Robert and Paula Tufis. (2003) "Precursors of Nonmarital Fertility in the United States." Journal of Marriage and the Family, 65: 1030-1040.

Schoen, Robert, Nan Marie Astone, Young J. Kim, Constance A. Nathanson, and Jason M. Fields. (1999). "Do Fertility Intentions Affect Fertility Behavior?” Journal of Marriage and the Family, 61: 790-799.

Schoen, Robert, Young J. Kim, Constance A. Nathanson, Jason Fields, and Nan Marie Aston. (1997). "Why Do Americans Want Children?" Population and Development Review, 23: 333-358.

Schulz, Reiner. (1996). „Der Familienstand als Determinante der Struktur des familialen Hilfsund Unterstützungsnetzwerks. "Zeitschrift für Bevölkerungswissenschaft, 21: 3-27.

Schwartz, Shalom H. (1994). "Are there Universal Aspects in the Structure and Contents of Human Values?” Journal of Social Issues, 50: 19-45.

Schweizer, Thomas. (1996). Muster sozialer Ordnung. Netzwerkanalyse als Fundament der Sozialethnologie. Berlin: Dietrich Reimer Verlag.

Shkolnikov, Vladimir M., Evgueni M. Andreev, René Houle, and James W. Vaupel. (2004). The Concentration of Reproduction in Cohorts of US and European Women. MPIDR Working Paper WP 2004-027, Max Planck Institute for Demographic Research, Rostock.

Sik, Endre. (1995). Network Capital in Capitalist, Communist, and Post-Communist Societies. Working Paper 212, The Helen Kellogg Institute for International Studies, University of Notre Dame, Notre Dame.

Spielauer, Martin. (2005). Second Birth Risks and Intentions in Bulgaria. Unpublished manuscript. Max Planck Institute for Demographic Research, Rostock.

Townes, Brenda D., Lee Roy Beach, Frederick L. Campbell, and Donald C. Martin. (1977). "Birth Planning Values and Decisions: The Prediction of Fertility." Journal of Applied Social Psychology, 7: 73-88.

Turchi, Boone A. (1975). "Microeconomic Theories of Fertility: A Critique." Social Forces, 54: 107-125.

van der Poel, Mart GM. (1993). Personal Networks: A Rational-Choice Explanation of Their Size and Composition. Lisse and Berwyn: Swets \& Zeitlinger. 
Table 1

Variables used in the analyses and their descriptive statistics

\begin{tabular}{|c|c|c|c|c|c|c|c|}
\hline & \multicolumn{6}{|c|}{ Kind of partnership } \\
\hline & & \multicolumn{4}{|c|}{ Marriage or cohabitation } & \multicolumn{2}{|c|}{$\begin{array}{l}\text { Intimate } \\
\text { Friend }\end{array}$} \\
\hline & & \multicolumn{4}{|c|}{ Parity } & \multicolumn{2}{|c|}{ Parity } \\
\hline & & \multicolumn{2}{|c|}{0} & \multicolumn{2}{|c|}{1} & \multicolumn{2}{|c|}{0} \\
\hline Variable & Description & Female & Male & Female & Male & Female & Male \\
\hline \multicolumn{8}{|c|}{ Dependent variable: } \\
\hline $\begin{array}{l}\text { Fertility } \\
\text { intention }\end{array}$ & $\begin{array}{l}\text { Intention to have a first or another child during } \\
\text { the next two years: } 1=\text { definitely not, } 2=\text { proba- } \\
\text { bly not, } 3=\text { probably yes, } 4=\text { definitely yes }\end{array}$ & $\begin{array}{c}2.92 \\
(1.062)\end{array}$ & $\begin{array}{c}2.88 \\
(1.033)\end{array}$ & $\begin{array}{c}2.14 \\
(0.994)\end{array}$ & $\begin{array}{c}2.24 \\
(0.941)\end{array}$ & $\begin{array}{c}2.11 \\
(0.987)\end{array}$ & $\begin{array}{c}1.91 \\
(0.919)\end{array}$ \\
\hline $\begin{array}{l}\text { Perceived } \\
\text { benefits }\end{array}$ & A first or another child would ... & & & & & & \\
\hline $\begin{array}{l}\text { Closeness with } \\
\text { partner }\end{array}$ & $\begin{array}{l}\ldots \text { increase the closeness between respondent } \\
\text { and his/her partner: } \\
1=\text { rather/completely agree, } 0=\text { neither agree } \\
\text { nor disagree, rather/completely disagree }\end{array}$ & $\begin{array}{l}0.79 \\
(0.405)\end{array}$ & $\begin{array}{l}0.84 \\
(0.364)\end{array}$ & $\begin{array}{l}0.62 \\
(0.486)\end{array}$ & $\begin{array}{l}0.72 \\
(0.447)\end{array}$ & $\begin{array}{l}0.72 \\
(0.447)\end{array}$ & $\begin{array}{l}0.82 \\
(0.384)\end{array}$ \\
\hline $\begin{array}{l}\text { Closeness with } \\
\text { parents and rela- } \\
\text { tives }\end{array}$ & $\begin{array}{l}\ldots \text { increase closeness between respondent and } \\
\text { his/her parents and relatives: } \\
1=\text { rather/completely agree, } 0=\text { neither agree } \\
\text { nor disagree, rather/completely disagree }\end{array}$ & $\begin{array}{l}0.70 \\
(0.461)\end{array}$ & $\begin{array}{l}0.71 \\
(0.454)\end{array}$ & $\begin{array}{l}0.54 \\
(0.499)\end{array}$ & $\begin{array}{l}0.62 \\
(0.486)\end{array}$ & $\begin{array}{l}0.61 \\
(0.488)\end{array}$ & $\begin{array}{l}0.72 \\
(0.449)\end{array}$ \\
\hline Old age security & $\begin{array}{l}\ldots \text { increase respondent's security that at old age } \\
\text { there is someone to care for him/her: } \\
1=\text { rather/completely agree, } 0=\text { neither agree } \\
\text { nor disagree, rather/completely disagree }\end{array}$ & $\begin{array}{l}0.52 \\
(0.501)\end{array}$ & $\begin{array}{l}0.62 \\
(0.486)\end{array}$ & $\begin{array}{l}0.45 \\
(0.498)\end{array}$ & $\begin{array}{l}0.50 \\
(0.500)\end{array}$ & $\begin{array}{l}0.45 \\
(0.498)\end{array}$ & $\begin{array}{l}0.54 \\
(0.499)\end{array}$ \\
\hline $\begin{array}{l}\text { Joy and satisfac- } \\
\text { tion }\end{array}$ & $\begin{array}{l}\ldots \text { increase joy and satisfaction in respondent's } \\
\text { life: } \\
1=\text { rather/completely agree, } 0=\text { neither agree } \\
\text { nor disagree, rather/completely disagree }\end{array}$ & $\begin{array}{l}0.91 \\
(0.283)\end{array}$ & $\begin{array}{l}0.94 \\
(0.230)\end{array}$ & $\begin{array}{l}0.89 \\
(0.309)\end{array}$ & $\begin{array}{l}0.87 \\
(0.335)\end{array}$ & $\begin{array}{l}0.91 \\
(0.286)\end{array}$ & $\begin{array}{l}0.89 \\
(0.318)\end{array}$ \\
\hline $\begin{array}{l}\text { Continuation into } \\
\text { the future }\end{array}$ & $\begin{array}{l}\ldots \text { means that a part of the respondent is contin- } \\
\text { ued into the future: } \\
1=\text { rather/completely agree, } 0=\text { neither agree } \\
\text { nor disagree, rather/completely disagree }\end{array}$ & $\begin{array}{l}0.52 \\
(0.501)\end{array}$ & $\begin{array}{l}0.91 \\
(0.288)\end{array}$ & $\begin{array}{l}0.87 \\
(0.333)\end{array}$ & $\begin{array}{l}0.88 \\
(0.322)\end{array}$ & $\begin{array}{l}0.94 \\
(0.244)\end{array}$ & $\begin{array}{l}0.91 \\
(0.283)\end{array}$ \\
\hline Perceived costs & A first or another child would ... & & & & & & \\
\hline $\begin{array}{l}\text { Economic } \\
\text { difficulties }\end{array}$ & $\begin{array}{l}\ldots \text { increase respondent's economic difficulties: } \\
1=\text { rather/completely agree, } 0=\text { neither agree } \\
\text { nor disagree, rather/completely disagree }\end{array}$ & $\begin{array}{l}0.77 \\
(0.419)\end{array}$ & $\begin{array}{l}0.71 \\
(0.454)\end{array}$ & $\begin{array}{l}0.79 \\
(0.410)\end{array}$ & $\begin{array}{l}0.78 \\
(0.416)\end{array}$ & $\begin{array}{l}.78 \\
0.417)\end{array}$ & $\begin{array}{l}.82 \\
0.383)\end{array}$ \\
\hline $\begin{array}{l}\text { Worries and } \\
\text { preoccupations }\end{array}$ & $\begin{array}{l}\ldots \text { increase worries and preoccupations in the } \\
\text { course of respondent's daily life: } \\
1=\text { rather/completely agree, } 0=\text { neither agree } \\
\text { nor disagree, rather/completely disagree }\end{array}$ & $\begin{array}{l}0.72 \\
(0.449)\end{array}$ & $\begin{array}{l}0.67 \\
(0.473)\end{array}$ & $\begin{array}{l}0.80 \\
(0.399)\end{array}$ & $\begin{array}{l}0.68 \\
(0.468)\end{array}$ & $\begin{array}{l}.80 \\
0.400)\end{array}$ & $\begin{array}{l}.77 \\
0.420)\end{array}$ \\
\hline $\begin{array}{l}\text { Less time at } \\
\text { disposal }\end{array}$ & $\begin{array}{l}\ldots \text { decrease time for respondent's personal } \\
\text { interests, for contacts with friends: } \\
1=\text { rather/completely agree, } 0=\text { neither agree } \\
\text { nor disagree, rather/completely disagree }\end{array}$ & $\begin{array}{l}0.69 \\
(0.465)\end{array}$ & $\begin{array}{l}0.65 \\
(0.478)\end{array}$ & $\begin{array}{l}0.74 \\
(0.439)\end{array}$ & $\begin{array}{l}0.60 \\
(0.490)\end{array}$ & $\begin{array}{l}.78 \\
0.417)\end{array}$ & $\begin{array}{l}.73 \\
0.447)\end{array}$ \\
\hline $\begin{array}{l}\text { Less career } \\
\text { perspectives }\end{array}$ & $\begin{array}{l}\ldots \text { decrease respondent's chances in his/her } \\
\text { working career and/or higher education: } \\
1=\text { rather/completely agree, } 0=\text { neither agree } \\
\text { nor disagree, rather/completely disagree }\end{array}$ & $\begin{array}{l}0.47 \\
(0.500)\end{array}$ & $\begin{array}{l}0.15 \\
(0.354)\end{array}$ & $\begin{array}{l}0.49 \\
(0.500)\end{array}$ & $\begin{array}{l}0.10 \\
(0.304)\end{array}$ & $\begin{array}{l}.57 \\
0.495)\end{array}$ & $\begin{array}{l}.31 \\
0.462)\end{array}$ \\
\hline Physical burden & $\begin{array}{l}\ldots \text { increase the physical burden for the respon- } \\
\text { dent because of the pregnancy, care for the baby, } \\
\text { or breastfeeding (asked only to female respon- } \\
\text { dents) } \\
1=\text { rather/completely agree, } 0=\text { neither agree } \\
\text { nor disagree, rather/completely disagree }\end{array}$ & $\begin{array}{l}0.49 \\
(0.501)\end{array}$ & -- & $\begin{array}{l}0.55 \\
(0.498)\end{array}$ & -- & $\begin{array}{l}.55 \\
0.498)\end{array}$ & -- \\
\hline
\end{tabular}

continued on the next page 
Table 1 (continued)

\begin{tabular}{|c|c|c|c|c|c|c|c|}
\hline \multicolumn{8}{|c|}{ Respondent's characteristics: } \\
\hline Age & Age at time of interview & & & & & & \\
\hline 18 to 25 & $1=$ yes, $0=$ no & $\begin{array}{c}0.49 \\
(0.501)\end{array}$ & $\begin{array}{l}0.28 \\
(0.449)\end{array}$ & $\begin{array}{l}0.31 \\
(0.464)\end{array}$ & $\begin{array}{l}0.11 \\
(0.314)\end{array}$ & $\begin{array}{l}0.68 \\
(0.467)\end{array}$ & $\begin{array}{l}0.64 \\
(0.479)\end{array}$ \\
\hline 26 to 30 & $1=$ yes, $0=$ no & $\begin{array}{l}0.38 \\
(0.487)\end{array}$ & $\begin{array}{l}0.42 \\
(0.495)\end{array}$ & $\begin{array}{l}0.42 \\
(0.493)\end{array}$ & $\begin{array}{l}0.35 \\
(0.477)\end{array}$ & $\begin{array}{l}0.24 \\
(0.425)\end{array}$ & $\begin{array}{l}0.30 \\
(0.458)\end{array}$ \\
\hline 31 to 35 & $\begin{array}{l}1=\text { yes, } 0=\text { no; reference category for female } \\
\text { respondents }\end{array}$ & $\begin{array}{l}0.13 \\
(0.335)\end{array}$ & $\begin{array}{l}0.24 \\
(0.427)\end{array}$ & $\begin{array}{l}0.27 \\
(0.443)\end{array}$ & $\begin{array}{l}0.35 \\
(0.478)\end{array}$ & $\begin{array}{l}0.08 \\
(0.276)\end{array}$ & 0.06 \\
\hline 36 to 66 & reference category for male respondents & -- & $\begin{array}{l}0.04 \\
(0.185)\end{array}$ & -- & $\begin{array}{l}0.15 \\
(0.357)\end{array}$ & -- & $(0.232)$ \\
\hline Cohabitation & Respondent lives in cohabitation: $1=$ yes, $0=$ no & $\begin{array}{l}0.50 \\
(0.501)\end{array}$ & $\begin{array}{l}0.47 \\
(0.500)\end{array}$ & -- & -- & -- & -- \\
\hline Siblings & Number of siblings the respondent has & $\begin{array}{l}0.99 \\
(0.692)\end{array}$ & $\begin{array}{l}1.09 \\
(0.798)\end{array}$ & $\begin{array}{l}1.10 \\
(0.806)\end{array}$ & $\begin{array}{l}1.03 \\
(0.650)\end{array}$ & $\begin{array}{l}0.95 \\
(0.513)\end{array}$ & $\begin{array}{l}0.96 \\
(0.571)\end{array}$ \\
\hline $\begin{array}{l}\text { Tertiary } \\
\text { education }\end{array}$ & $\begin{array}{l}\text { Respondent has completed tertiary education: } \\
1=\text { yes, } 0=\text { no }\end{array}$ & $\begin{array}{l}0.50 \\
(0.501)\end{array}$ & $\begin{array}{l}0.25 \\
(0.436)\end{array}$ & $\begin{array}{l}0.33 \\
(0.469)\end{array}$ & $\begin{array}{l}0.18 \\
(0.385)\end{array}$ & $\begin{array}{l}0.33 \\
(0.472)\end{array}$ & $\begin{array}{l}0.13 \\
(0.338)\end{array}$ \\
\hline $\begin{array}{l}\text { Intention to start } \\
\text { education }\end{array}$ & $\begin{array}{l}\text { Respondent intents to start education within the } \\
\text { next two years: } 1=\text { yes, } 0=\text { no }\end{array}$ & $\begin{array}{l}0.15 \\
(0.362)\end{array}$ & $\begin{array}{l}0.11 \\
(0.309)\end{array}$ & -- & -- & $\begin{array}{l}0.25 \\
(0.431)\end{array}$ & $\begin{array}{l}0.20 \\
(0.398)\end{array}$ \\
\hline $\begin{array}{l}\text { Income from } \\
\text { labor }\end{array}$ & $\begin{array}{l}\text { Respondent generated income from employment } \\
\text { or self-employment during the last three months: } \\
1=\text { yes, } 0=\text { no }\end{array}$ & $(0.460)$ & $\begin{array}{l}0.83 \\
(0.378)\end{array}$ & $\begin{array}{l}0.53 \\
(0.500)\end{array}$ & $\begin{array}{l}0.88 \\
(0.331)\end{array}$ & $\begin{array}{l}0.62 \\
(0.485)\end{array}$ & $\begin{array}{l}0.67 \\
(0.471)\end{array}$ \\
\hline Religiousness & $\begin{array}{l}\text { Respondent perceives himself/herself as a } \\
\text { religious person: } 1=\text { yes, } 0=\text { no }\end{array}$ & $\begin{array}{l}0.59 \\
(0.492)\end{array}$ & $\begin{array}{l}0.43 \\
(0.470)\end{array}$ & $\begin{array}{l}0.61 \\
(0.487)\end{array}$ & $\begin{array}{l}0.43 \\
(0.495)\end{array}$ & $\begin{array}{l}0.66 \\
(0.473)\end{array}$ & $\begin{array}{l}0.42 \\
(0.495)\end{array}$ \\
\hline \multicolumn{8}{|c|}{ Household's characteristics: } \\
\hline $\begin{array}{l}\text { Equivalence } \\
\text { income (log) }\end{array}$ & $\begin{array}{l}\text { Logarithm of equivalence income of the house- } \\
\text { hold }\end{array}$ & $\begin{array}{l}2.87 \\
(0.736)\end{array}$ & $\begin{array}{l}2.88 \\
(0.821)\end{array}$ & $\begin{array}{l}2.69 \\
(0.654)\end{array}$ & $\begin{array}{l}2.71 \\
(0.672)\end{array}$ & $\begin{array}{l}2.80 \\
(0.585)\end{array}$ & $\begin{array}{l}2.82 \\
(0.680)\end{array}$ \\
\hline Countryside & $\begin{array}{l}\text { Household is located in the countryside: } 1=\text { yes, } \\
0=\text { no }\end{array}$ & $\begin{array}{l}0.86 \\
(0.346)\end{array}$ & $\begin{array}{l}0.83 \\
(0.374)\end{array}$ & $\begin{array}{l}0.85 \\
(0.362)\end{array}$ & $\begin{array}{l}0.84 \\
(0.371)\end{array}$ & $\begin{array}{l}0.90 \\
(0.301)\end{array}$ & $\begin{array}{l}0.87 \\
(0.336)\end{array}$ \\
\hline $\mathrm{N}$ & & 195 & 198 & 996 & 914 & 457 & 456 \\
\hline
\end{tabular}

Reported are means and standard deviations (in parentheses). 
Table 2

Intentions to have a first or another child within the next two years of male and female respondents by kind of relationship and parity

a) Female respondents

\begin{tabular}{|c|c|c|c|c|c|}
\hline & \multicolumn{5}{|c|}{ Kind of partnership } \\
\hline & \multirow{2}{*}{$\begin{array}{c}\text { Intimate } \\
\text { friend }\end{array}$} & \multicolumn{4}{|c|}{ Marriage or cohabitation } \\
\hline & & \multicolumn{4}{|c|}{ Parity } \\
\hline & 0 & 0 & 1 & 2 & 3 or more \\
\hline Definitely yes & 10.7 & 36.1 & 10.1 & 1.0 & 2.4 \\
\hline Probably yes & 22.2 & 32.4 & 25.5 & 2.7 & 2.4 \\
\hline Probably not & 32.0 & 16.2 & 31.5 & 16.4 & 7.1 \\
\hline Definitely not & 35.0 & 15.3 & 32.9 & 79.9 & 88.1 \\
\hline Total & 99.9 & 100.0 & 100.0 & 100.0 & 100.0 \\
\hline $\mathrm{N}$ & 540 & 216 & 1,095 & 603 & 42 \\
\hline
\end{tabular}

b) Male respondents

\begin{tabular}{lccrrr}
\hline & \multicolumn{5}{c}{ Kind of partnership } \\
\cline { 2 - 6 } & $\begin{array}{l}\text { Intimate } \\
\text { friend }\end{array}$ & \multicolumn{5}{c}{ Marriage or cohabitation } \\
\cline { 2 - 6 } & Parity & 0 & 1 & 2 & 3 or more \\
\cline { 2 - 6 } & 0 & 33.8 & 9.7 & 1.1 & -- \\
\hline Definitely yes & 6.1 & 33.3 & 29.8 & 4.4 & 1.7 \\
Probably yes & 18.1 & 18.3 & 35.1 & 26.6 & 23.7 \\
Probably not & 35.7 & 14.6 & 25.4 & 67.9 & 74.6 \\
Definitely not & 40.0 & 100.0 & 100.0 & 100.0 & 100.0 \\
\hline Total & 99.9 & 219 & 1,020 & 616 & 59 \\
\hline $\mathrm{N}$ & 557 & & & & \\
\hline
\end{tabular}


Table 3:

Determinants of intentions to have a first or a second child within the next two years: respondents who are married or live in cohabitation by parity and gender (ordinal logit regression)

\begin{tabular}{|c|c|c|c|c|c|c|c|c|}
\hline & \multicolumn{8}{|c|}{ Parity } \\
\hline & \multicolumn{4}{|c|}{0} & \multicolumn{4}{|c|}{1} \\
\hline & \multicolumn{2}{|c|}{ Females } & \multicolumn{2}{|c|}{ Males } & \multicolumn{2}{|c|}{ Females } & \multicolumn{2}{|c|}{ Males } \\
\hline & $\begin{array}{l}\text { Coef. } \\
\text { (SE) }\end{array}$ & Sign. & $\begin{array}{l}\text { Coef. } \\
\text { (SE) }\end{array}$ & Sign. & $\begin{array}{l}\text { Coef. } \\
\text { (SE) }\end{array}$ & Sign. & $\begin{array}{l}\text { Coef. } \\
\text { (SE) }\end{array}$ & Sign. \\
\hline \multicolumn{9}{|l|}{ Perceived benefits } \\
\hline Closeness with partner & $\begin{array}{c}0.441 \\
0.463)\end{array}$ & 0.342 & $\begin{array}{l}-0.061 \\
(0.422)\end{array}$ & 0.886 & $\begin{array}{l}0.449 \\
(0.161)\end{array}$ & 0.005 & $\begin{array}{l}0.053 \\
(0.172)\end{array}$ & 0.756 \\
\hline $\begin{array}{l}\text { Closeness with parents and } \\
\text { relatives }\end{array}$ & $\begin{array}{l}1.002 \\
(0.393)\end{array}$ & .011 & $\begin{array}{l}0.431 \\
(0.360)\end{array}$ & 0.231 & $\begin{array}{l}0.147 \\
(0.155)\end{array}$ & 0.344 & $\begin{array}{l}0.136 \\
(0.154)\end{array}$ & 0.376 \\
\hline Old age security & $\begin{array}{l}-0.303 \\
(0.290)\end{array}$ & .296 & $\begin{array}{l}0.742 \\
(0.312)\end{array}$ & 0.017 & $\begin{array}{l}0.060 \\
(0.127)\end{array}$ & 0.636 & $\begin{array}{l}0.192 \\
(0.130)\end{array}$ & 0.140 \\
\hline Joy and satisfaction & $\begin{array}{l}0.598 \\
(0.591)\end{array}$ & .286 & $\begin{array}{l}0.445 \\
(0.606)\end{array}$ & 0.324 & $\begin{array}{l}0.705 \\
(0.211)\end{array}$ & 0.001 & $\begin{array}{l}0.652 \\
(0.205)\end{array}$ & 0.001 \\
\hline Continuation into the future & $\begin{array}{l}0.249 \\
(0.509)\end{array}$ & .625 & $\begin{array}{l}-0.507 \\
(0.479)\end{array}$ & 0.291 & $\begin{array}{l}0.232 \\
(0.196)\end{array}$ & 0.237 & $\begin{array}{l}0.306 \\
(0.210)\end{array}$ & 0.145 \\
\hline \multicolumn{9}{|l|}{ Perceived costs } \\
\hline Economic difficulties & $\begin{array}{c}0.846 \\
0.407)\end{array}$ & 0.038 & $\begin{array}{r}0.034 \\
0.326)\end{array}$ & .917 & $\begin{array}{c}0.781 \\
0.156)\end{array}$ & 0.000 & $\begin{array}{l}0.662 \\
0.156)\end{array}$ & 0.000 \\
\hline Worries and preoccupations & $\begin{array}{c}0.093 \\
0.378)\end{array}$ & 0.805 & $\begin{array}{c}0.216 \\
0.331)\end{array}$ & .513 & $\begin{array}{c}0.157 \\
0.174)\end{array}$ & 0.367 & $\begin{array}{c}0.033 \\
0.149)\end{array}$ & 0.825 \\
\hline Less time at disposal & $\begin{array}{c}.023 \\
0.359)\end{array}$ & 0.949 & $\begin{array}{c}.205 \\
0.348)\end{array}$ & .556 & $\begin{array}{c}.216 \\
0.155)\end{array}$ & 0.162 & $\begin{array}{c}0.273 \\
0.144)\end{array}$ & 0.058 \\
\hline Less career perspectives & $\begin{array}{c}0.611 \\
0.306)\end{array}$ & 0.046 & $\begin{array}{c}0.785 \\
0.414)\end{array}$ & .058 & $\begin{array}{c}0.115 \\
0.129)\end{array}$ & 0.371 & $\begin{array}{c}0.217 \\
0.155)\end{array}$ & 0.160 \\
\hline Physical burden & $\begin{array}{l}.713 \\
0.321)\end{array}$ & 0.026 & -- & -- & $\begin{array}{c}0.380 \\
0.134)\end{array}$ & 0.005 & -- & -- \\
\hline \multicolumn{9}{|c|}{ Respondent's characteristics } \\
\hline 18 to 25 & $\begin{array}{l}0.523 \\
(0.442)\end{array}$ & .237 & $\begin{array}{l}1.046 \\
(0.639)\end{array}$ & 0.102 & $\begin{array}{l}0.120 \\
(0.171)\end{array}$ & 0.481 & $\begin{array}{l}0.245 \\
(0.238)\end{array}$ & 0.304 \\
\hline 26 to 30 & $\begin{array}{l}1.151 \\
(0.444)\end{array}$ & .010 & $\begin{array}{l}1.119 \\
(0.629)\end{array}$ & 0.075 & $\begin{array}{l}0.221 \\
(0.149)\end{array}$ & 0.139 & $\begin{array}{l}0.530 \\
(0.177)\end{array}$ & 0.003 \\
\hline 31 to 35 & -- & -- & $\begin{array}{l}0.226 \\
(0.662)\end{array}$ & 0.733 & -- & -- & $\begin{array}{l}0.419 \\
(0.177)\end{array}$ & 0.018 \\
\hline Cohabitation $^{\mathrm{a}}$ & $\begin{array}{l}0.121 \\
(0.297)\end{array}$ & .683 & $\begin{array}{c}-0.346 \\
(0.281)\end{array}$ & 0.219 & -- & -- & -- & -- \\
\hline Siblings & $\begin{array}{l}-0.090 \\
(0.202)\end{array}$ & .655 & $\begin{array}{c}-0.273 \\
(0.180)\end{array}$ & 0.129 & $\begin{array}{c}-0.007 \\
(0.077)\end{array}$ & 0.928 & $\begin{array}{l}0.101 \\
(0.094)\end{array}$ & 0.281 \\
\hline Tertiary education & $\begin{array}{l}0.280 \\
(0.333)\end{array}$ & .401 & $\begin{array}{c}-0.113 \\
(0.346)\end{array}$ & 0.743 & $\begin{array}{l}0.268 \\
(0.139)\end{array}$ & 0.154 & $\begin{array}{l}0.173 \\
(0.167)\end{array}$ & 0.300 \\
\hline Intention to start education $^{\mathrm{a}}$ & $\begin{array}{l}-0.467 \\
(0.378)\end{array}$ & .217 & $\begin{array}{c}-0.277 \\
(0.490)\end{array}$ & 0.572 & -- & -- & -- & -- \\
\hline Income from labor & $\begin{array}{l}0.463 \\
(0.326)\end{array}$ & .156 & $\begin{array}{l}0.679 \\
(0.417)\end{array}$ & 0.103 & $\begin{array}{l}0.128 \\
(0.126)\end{array}$ & 0.306 & $\begin{array}{c}-0.100 \\
(0.201)\end{array}$ & 0.619 \\
\hline Religiousness & $\begin{array}{l}0.254 \\
(0.280)\end{array}$ & .365 & $\begin{array}{l}0.047 \\
(0.281)\end{array}$ & 0.868 & $\begin{array}{l}0.194 \\
(0.122)\end{array}$ & 0.112 & $\begin{array}{l}0.234 \\
(0.124)\end{array}$ & 0.059 \\
\hline \multicolumn{9}{|l|}{ Household's characteristics } \\
\hline Equivalence income (log) & $\begin{array}{c}-0.459 \\
(0.222)\end{array}$ & .039 & $\begin{array}{c}-0.372 \\
(0.212)\end{array}$ & 0.079 & $\begin{array}{l}0.096 \\
(0.100)\end{array}$ & 0.336 & $\begin{array}{l}0.262 \\
(0.106)\end{array}$ & 0.013 \\
\hline Countryside & $\begin{array}{l}0.321 \\
(0.415)\end{array}$ & .439 & $\begin{array}{l}0.731 \\
(0.421) \\
\end{array}$ & 0.083 & $\begin{array}{c}-0.185 \\
(0.172) \\
\end{array}$ & 0.283 & $\begin{array}{c}-0.054 \\
(0.177) \\
\end{array}$ & 0.760 \\
\hline \multicolumn{9}{|l|}{ Cut points } \\
\hline 1 & $\begin{array}{c}1.541 \\
0.968)\end{array}$ & & $\begin{array}{c}1.093 \\
1.138)\end{array}$ & & $\begin{array}{c}.069 \\
0.430)\end{array}$ & & $\begin{array}{c}.328 \\
0.404)\end{array}$ & \\
\hline 2 & $\begin{array}{c}0.438 \\
0.963)\end{array}$ & & $\begin{array}{l}.081 \\
1.132)\end{array}$ & & $\begin{array}{c}.479 \\
0.433)\end{array}$ & & $\begin{array}{c}.939 \\
0.410)\end{array}$ & \\
\hline 3 & $\begin{array}{c}.106 \\
0.967)\end{array}$ & & $\begin{array}{l}.755 \\
1.137) \\
\end{array}$ & & $\begin{array}{l}.185 \\
0.441) \\
\end{array}$ & & $\begin{array}{c}.868 \\
0.424) \\
\end{array}$ & \\
\hline $\begin{array}{l}\text { LL } \\
\chi^{2}(\mathrm{df})\end{array}$ & $\begin{array}{r}-23 \\
39 . \\
\end{array}$ & $\begin{array}{l}5.104 \\
88(20) \\
\end{array}$ & $\begin{array}{r}-24 \\
36.1 \\
\end{array}$ & $\begin{array}{l}.918 \\
(20)\end{array}$ & $\begin{array}{r}-12 \\
128 \\
\end{array}$ & $\begin{array}{l}46.235 \\
25(18)\end{array}$ & $\begin{array}{c}-11 \\
93 .\end{array}$ & $\begin{array}{l}828 \\
18) \\
\end{array}$ \\
\hline $\mathrm{N}$ & & 195 & & 98 & & 96 & & \\
\hline
\end{tabular}


Table 4:

Determinants of intentions to have a first child within the next two years: childless respondents who have a serious intimate friend for at least three months by gender (ordinal logit regression)

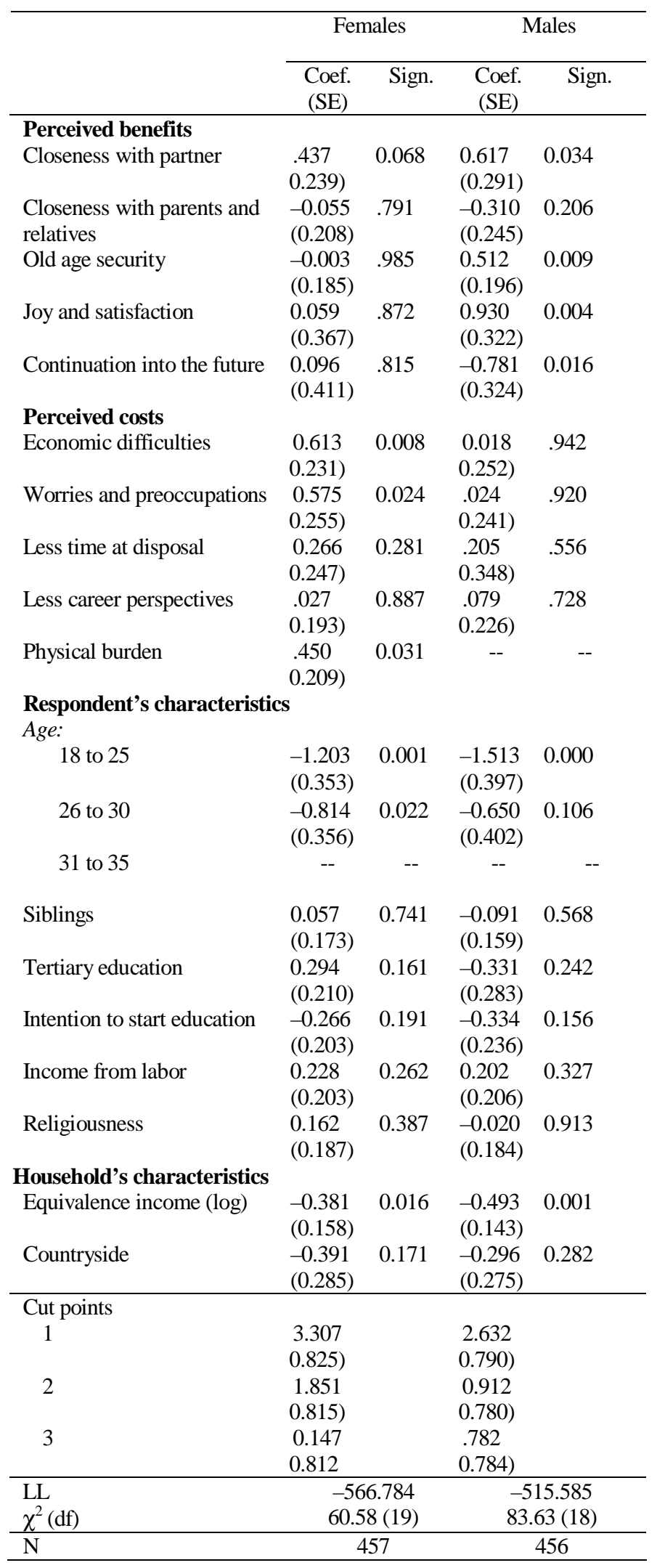

Unstandardized coefficients (standard errors) and significance levels are reported 
Figure 1:

Expected benefits of having a child by respondent's gender, kind of partnership, and parity

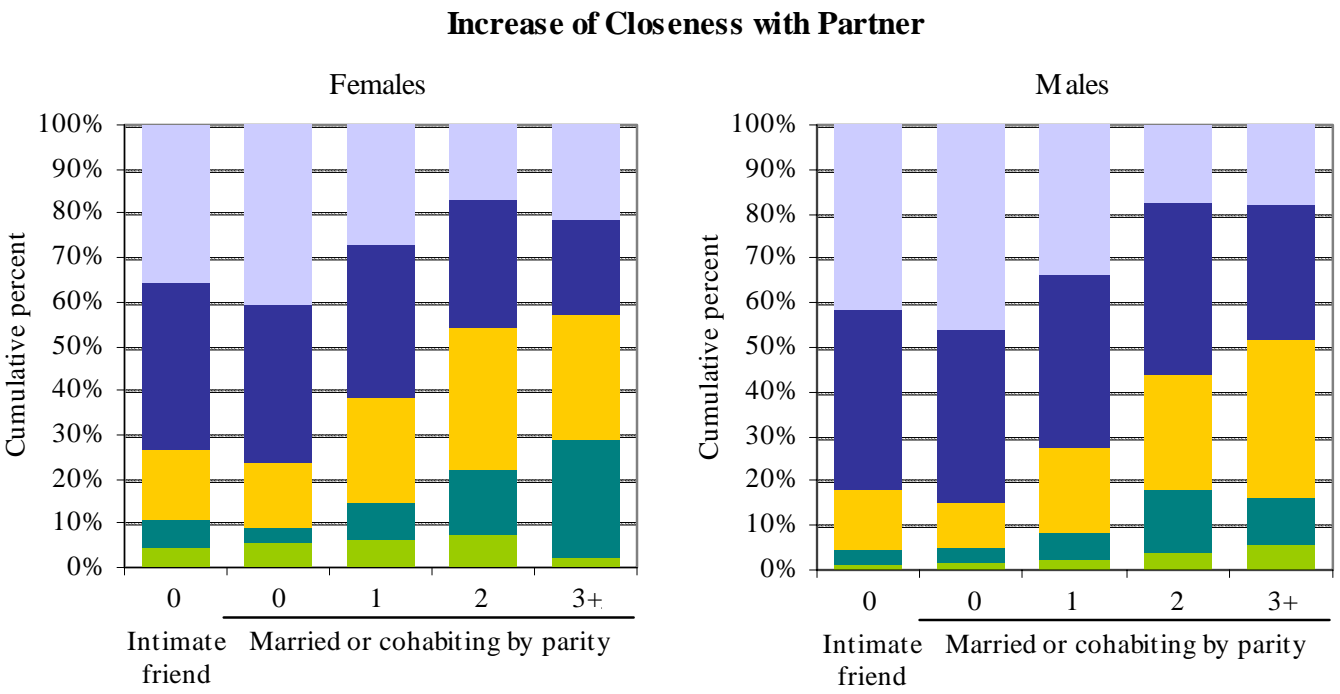

Increase of Closeness with Parents and Relatives

Females

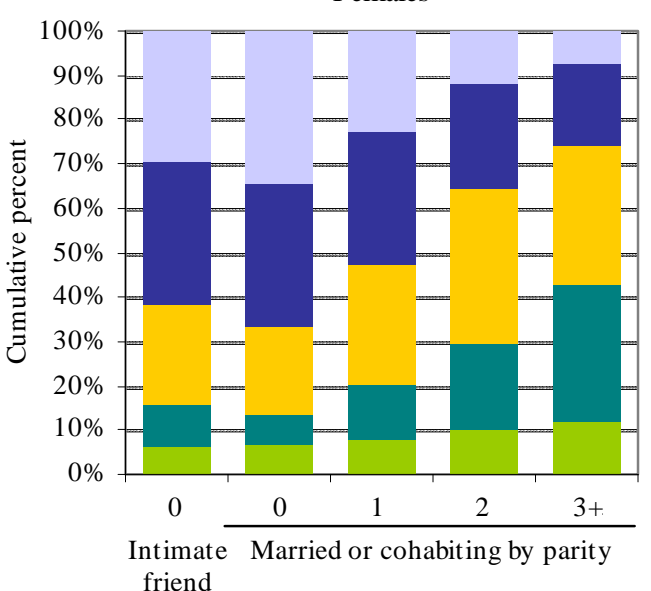

Males

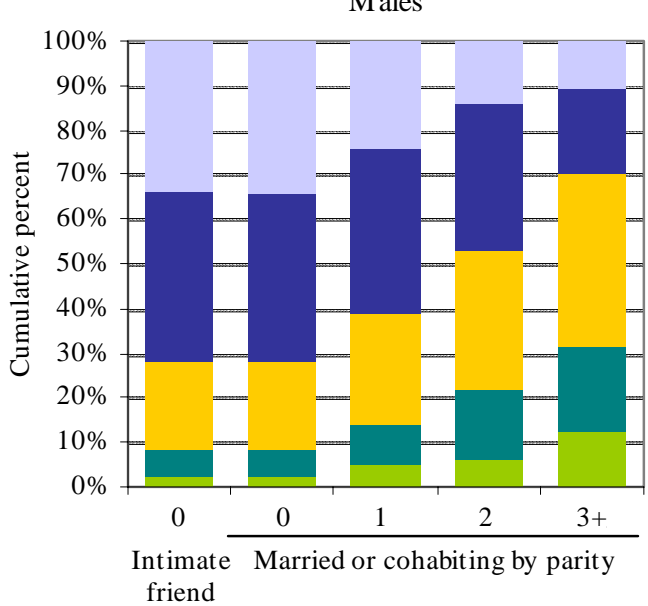

Old Age Security

Females

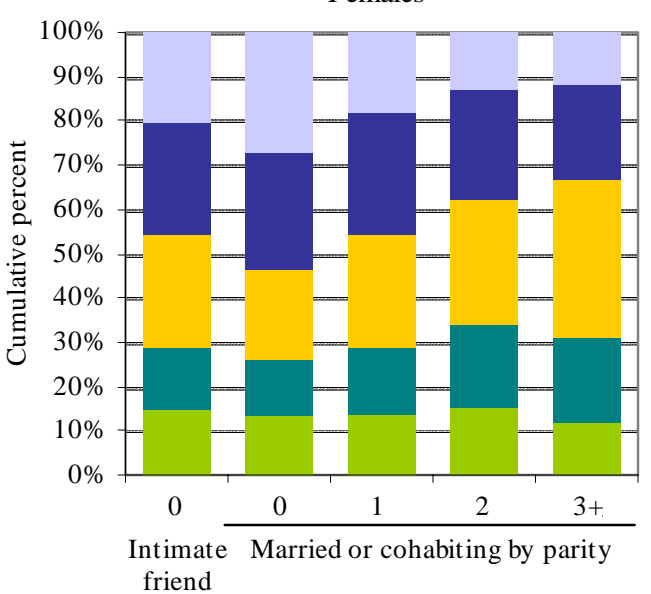

Males

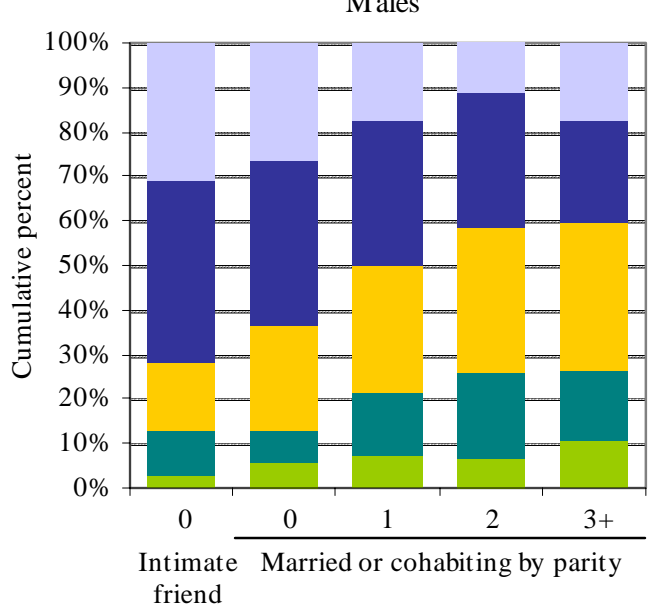


Figure 1 (continued):

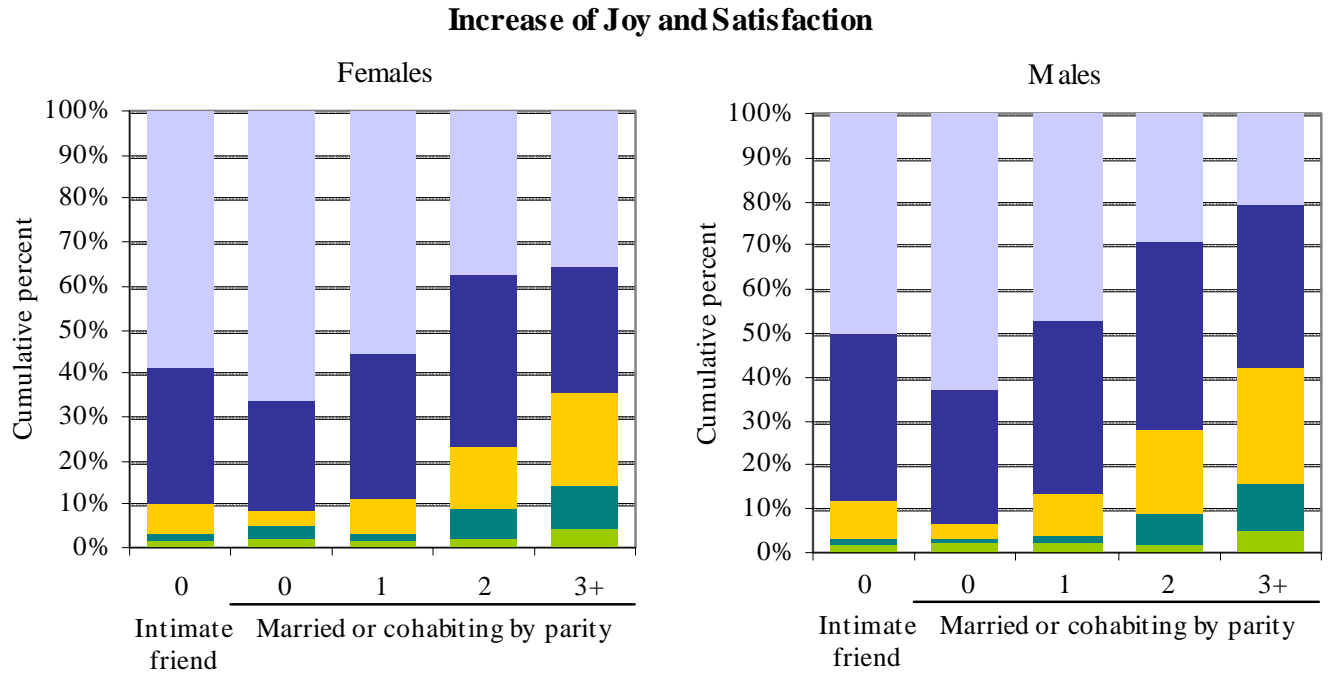

Continuation into the Future
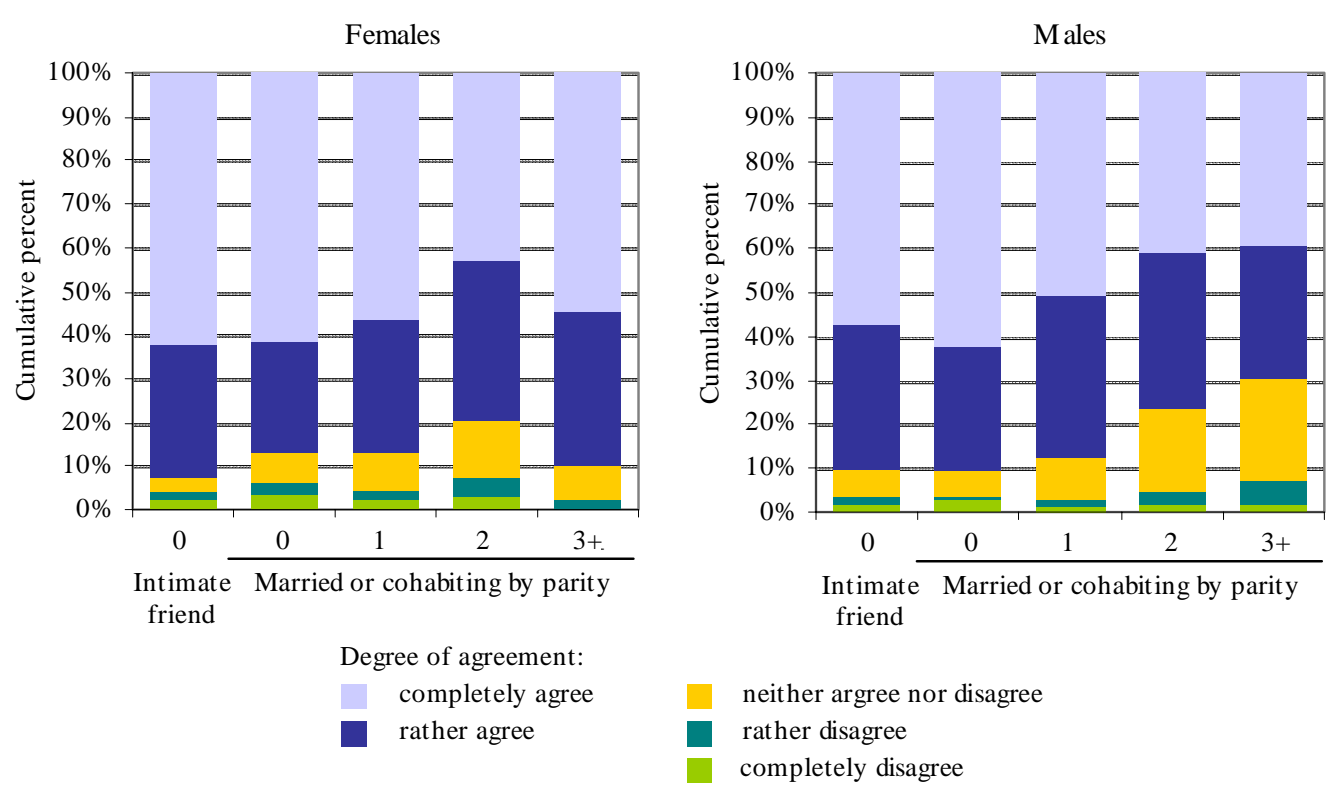
Figure 2:

Expected costs of having a child by respondent's gender, kind of partnership, and parity

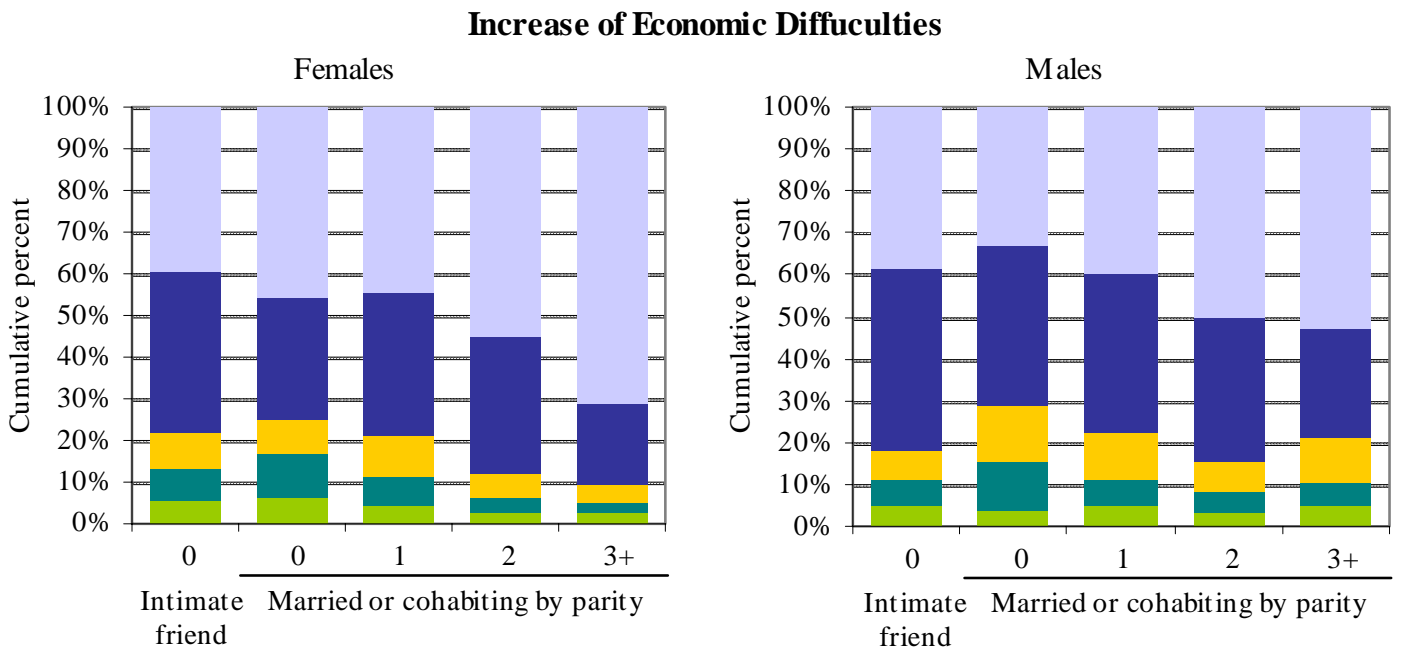

Increase of Worries and Preoccupations in the Daily Life
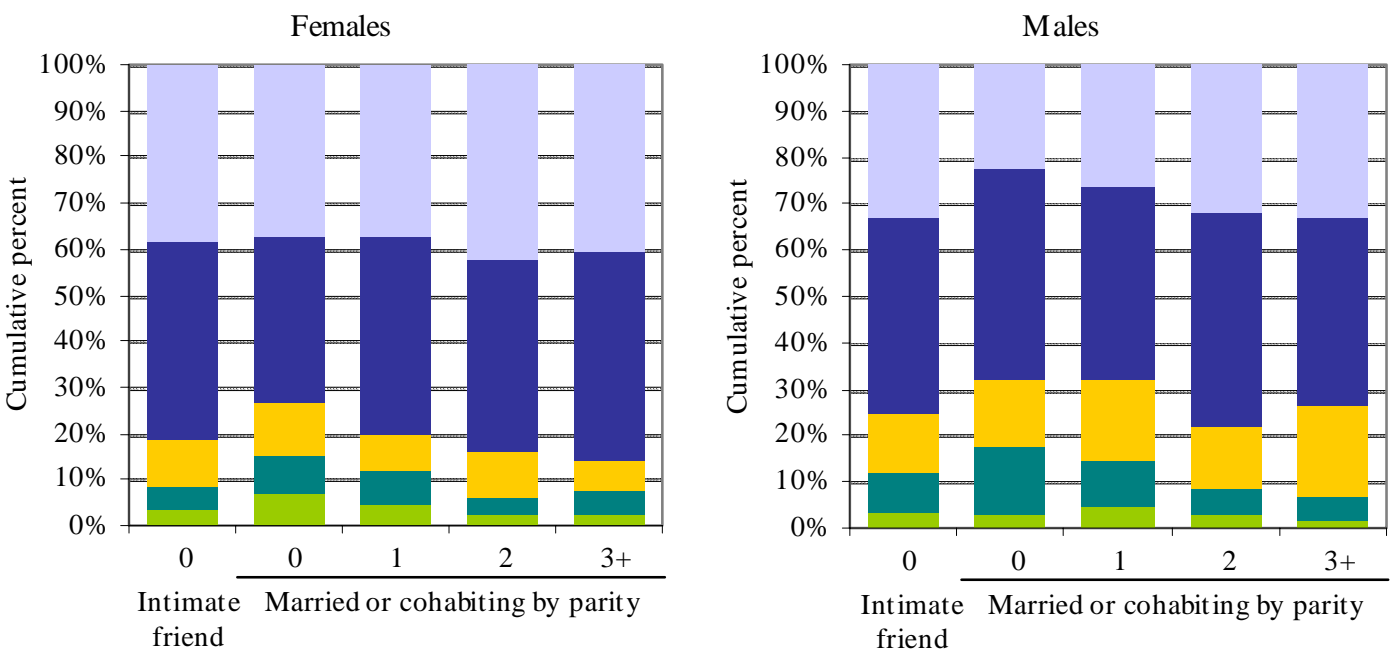

Decrease of Time for Personal Interests, for Contacts with Friends

Females

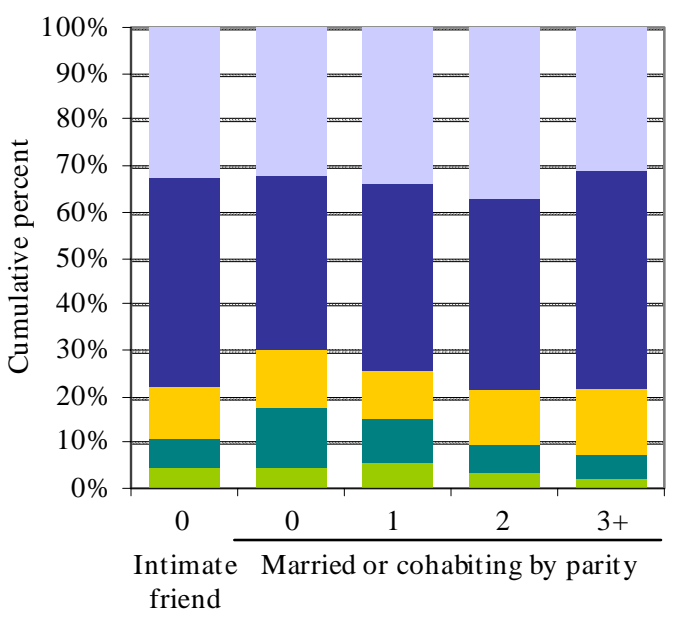

Males

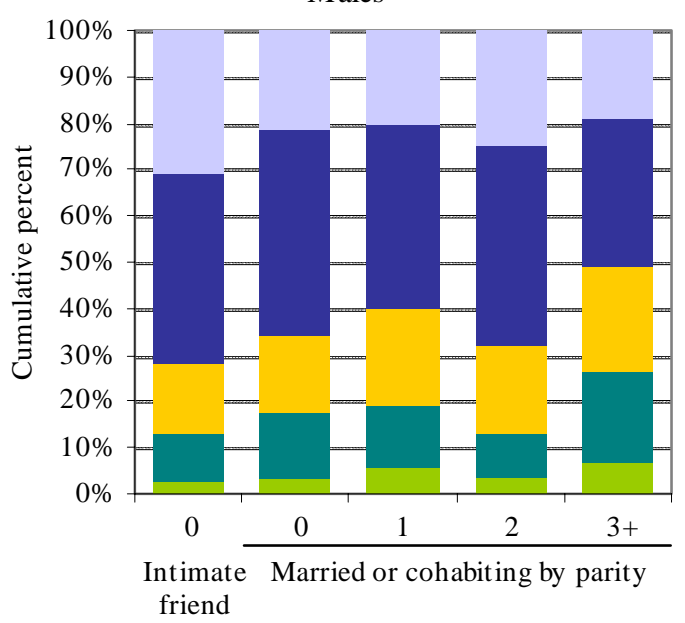


Figure 2 (continued):

Decrease of Chances in Working Career and/or Higher Education
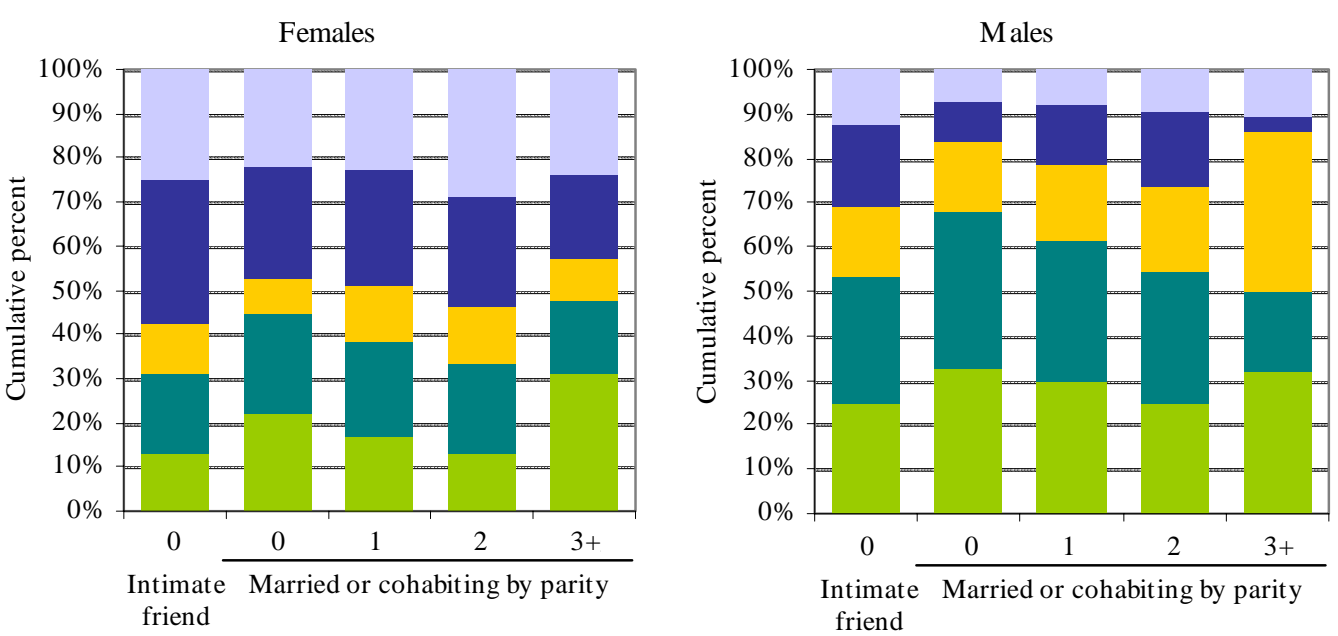

Increase of Physical Burden because of the

Pregnancy, the Care for the Baby, or Breastfeeding

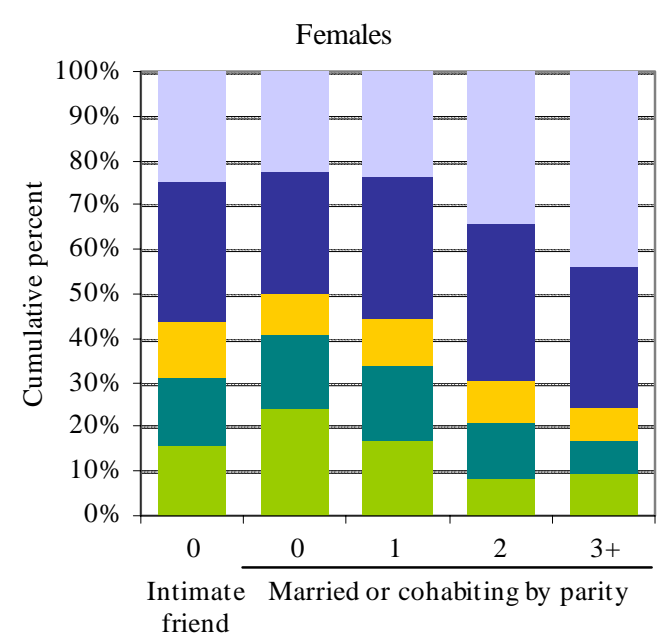

Degree of agreement:

completely agree

rather agree

neither argree nor disagree

rather disagree

completely disagree 


\section{Appendix A: Instrument used to measure the expected benefits and costs of children}

I am now going to ask you something about having children.

Interviewer, neither of the possible answers should be assessed as positive or negative.

\begin{tabular}{|c|l|c|c|c|c|c|}
\hline & $\begin{array}{l}\text { If you would have a child during the next two } \\
\text { years, irrespective of whether you really wish } \\
\text { to have a child or not, to what extent do you } \\
\text { agree that this would: }\end{array}$ & $\begin{array}{c}\text { Comp. } \\
\text { dis- } \\
\text { agree }\end{array}$ & $\begin{array}{c}\text { Rather } \\
\text { dis- } \\
\text { agree }\end{array}$ & $\begin{array}{c}\text { Neither } \\
\text { agree } \\
\text { nor } \\
\text { dis- } \\
\text { agree }\end{array}$ & $\begin{array}{c}\text { Rather } \\
\text { agree }\end{array}$ & $\begin{array}{c}\text { Comp. } \\
\text { agree }\end{array}$ \\
\hline A & increase your economic difficulties & 1 & 2 & 3 & 4 & 5 \\
\hline B & $\begin{array}{l}\text { decrease your chances in your working career } \\
\text { and/or higher education }\end{array}$ & 1 & 2 & 3 & 4 & 5 \\
\hline C & $\begin{array}{l}\text { increase your security that at old age because } \\
\text { there is someone who cares for you }\end{array}$ & 1 & 2 & 3 & 4 & 5 \\
\hline D & $\begin{array}{l}\text { increase uncertainty in your life } \\
\text { E }\end{array} \begin{array}{l}\text { This response is for females only! } \\
\text { increase the physical burden for you because } \\
\text { of the pregnancy, the care for the baby, or } \\
\text { breastfeeding }\end{array}$ & 1 & 2 & 3 & 4 & 5 \\
\hline F & increase joy and satisfaction in your life & 1 & 2 & 3 & 4 & 5 \\
\hline G & $\begin{array}{l}\text { increase worries and preoccupations in the } \\
\text { course of your daily life }\end{array}$ & 1 & 2 & 3 & 4 & 5 \\
\hline H & $\begin{array}{l}\text { decrease time for your personal interests, for } \\
\text { contacts with friends }\end{array}$ & 1 & 2 & 3 & 4 & 5 \\
\hline I & increase certainty in your life & 1 & 2 & 3 & 4 & 5 \\
\hline J & $\begin{array}{l}\text { increase the closeness between you and your } \\
\text { partner }\end{array}$ & 1 & 2 & 3 & 4 & 5 \\
\hline K & $\begin{array}{l}\text { increase the closeness between you and your } \\
\text { parents and relatives }\end{array}$ & 1 & 2 & 3 & 4 & 5 \\
\hline L & $\begin{array}{l}\text { mean that a part of you is continued into the } \\
\text { future }\end{array}$ & 1 & 2 & 3 & 4 & 5 \\
\hline
\end{tabular}




\section{Appendix B.1: Expected benefits of having children by kind of partnership, parity, and gender}

Increase of closeness between the respondent and his/her partner

\begin{tabular}{|c|c|c|c|c|c|c|c|c|c|c|}
\hline & \multicolumn{10}{|c|}{ Kind of partnership } \\
\hline & \multirow{2}{*}{\multicolumn{2}{|c|}{$\begin{array}{c}\text { Intimate friend } \\
\text { Parity }\end{array}$}} & \multicolumn{8}{|c|}{ Marriage or cohabitation } \\
\hline & & & \multicolumn{8}{|c|}{ Parity } \\
\hline & \multicolumn{2}{|c|}{0} & \multicolumn{2}{|c|}{0} & \multicolumn{2}{|c|}{1} & \multicolumn{2}{|c|}{2} & \multicolumn{2}{|c|}{$\geq 3$} \\
\hline & Female & Male & Female & Male & Female & Male & Female & Male & Female & Male \\
\hline $\begin{array}{l}\text { Completely } \\
\text { agree }\end{array}$ & 35.8 & 41.5 & 40.7 & 45.8 & 27.2 & 33.7 & 16.8 & 17.6 & 21.4 & 17.9 \\
\hline Rather agree & 37.5 & 40.3 & 35.7 & 39.0 & 34.5 & 38.7 & 29.1 & 38.8 & 21.4 & 30.4 \\
\hline $\begin{array}{l}\text { Neither agree } \\
\text { nor disagree }\end{array}$ & 16.1 & 13.5 & 14.3 & 10.0 & 23.8 & 19.3 & 31.9 & 25.6 & 28.6 & 35.7 \\
\hline $\begin{array}{l}\text { Rather } \\
\text { disagree }\end{array}$ & 6.2 & 3.3 & 3.9 & 3.6 & 8.4 & 6.1 & 15.0 & 14.3 & 26.2 & 10.7 \\
\hline $\begin{array}{l}\text { Completely } \\
\text { disagree }\end{array}$ & 4.4 & 1.3 & 5.4 & 1.6 & 6.1 & 2.2 & 7.2 & 3.8 & 2.4 & 5.4 \\
\hline Total & 100.0 & 99.9 & 100.0 & 100.0. & 100.0 & 100.0 & 100.0 & 100.1 & 100.0 & 100.1 \\
\hline $\mathrm{N}$ & 614 & 600 & 258 & 251 & 1,103 & 1,020 & 608 & 614 & 42 & 56 \\
\hline$\chi^{2}(\mathrm{df}=4)$ & & & & & & & & & & \\
\hline
\end{tabular}

Significance between childless respondents with an intimate friend and married or cohabiting childless respondents: females: $\chi^{2}=3.857$, sign $=0.425$; males: $\chi^{2}=2.753$, sign $=0.602$.

\section{Increase of closeness between the respondent and his/her parents and relatives}

\begin{tabular}{|c|c|c|c|c|c|c|c|c|c|c|}
\hline & \multicolumn{10}{|c|}{ Kind of partnership } \\
\hline & \multirow{3}{*}{\multicolumn{2}{|c|}{$\begin{array}{c}\text { Intimate friend } \\
\text { Parity } \\
0\end{array}$}} & & & $\mathrm{Ma}$ & lage or & nabitation & & & \\
\hline & & & \multirow{2}{*}{\multicolumn{2}{|c|}{0}} & & $\mathrm{Par}$ & ra & & & \\
\hline & & & & & \multicolumn{2}{|c|}{1} & \multicolumn{2}{|c|}{2} & \multicolumn{2}{|c|}{$\geq 3$} \\
\hline & Female & Male & Female & Male & Female & Male & Female & Male & Female & Male \\
\hline $\begin{array}{l}\text { Completely } \\
\text { agree }\end{array}$ & 29.4 & 33.8 & 34.4 & 34.3 & 22.4 & 24.1 & 11.8 & 14.0 & 7.1 & 10.5 \\
\hline Rather agree & 32.5 & 37.8 & 32.0 & 37.5 & 30.1 & 37.4 & 23.9 & 33.1 & 19.1 & 19.3 \\
\hline $\begin{array}{l}\text { Neither agree } \\
\text { nor disagree }\end{array}$ & 22.3 & 19.7 & 20.1 & 19.9 & 27.3 & 24.5 & 34.9 & 31.2 & 31.0 & 38.6 \\
\hline $\begin{array}{l}\text { Rather } \\
\text { disagree }\end{array}$ & 9.5 & 6.5 & 7.0 & 6.4 & 12.2 & 9.2 & 19.4 & 15.3 & 31.0 & 19.3 \\
\hline $\begin{array}{l}\text { Completely } \\
\text { disagree }\end{array}$ & 6.4 & 2.2 & 6.6 & 2.0 & 8.1 & 4.9 & 10.0 & 6.4 & 11.9 & 12.3 \\
\hline Total & 100.1 & 100.0 & 100.1 & 100.1 & 100.1 & 100.1 & 100.0 & 100.0 & 100.1 & 100.0 \\
\hline $\mathrm{N}$ & 613 & 600 & 259 & 251 & 1,101 & 1,022 & 608 & 613 & 42 & 57 \\
\hline$\chi^{2}(\mathrm{df}=4)$ & $\begin{array}{l}21 . \\
(0 .\end{array}$ & & & & $\begin{array}{l}23 . \\
(0 .\end{array}$ & & & & & \\
\hline
\end{tabular}

Significance between childless respondents with an intimate friend and married or cohabiting childless respondents: females: $\chi^{2}=3.248$, sign $=0.517$; males: $\chi^{2}=0.052$, sign $=1.000$. 
Increase in respondent's assurance that at old age there is someone who cares for him/her

\begin{tabular}{|c|c|c|c|c|c|c|c|c|c|c|}
\hline & \multicolumn{10}{|c|}{ Kind of partnership } \\
\hline & \multirow{3}{*}{\multicolumn{2}{|c|}{$\begin{array}{c}\text { Intimate friend } \\
\text { Parity } \\
0\end{array}$}} & \multirow{2}{*}{\multicolumn{8}{|c|}{$\begin{array}{c}\text { Marriage or cohabitation } \\
\text { Parity }\end{array}$}} \\
\hline & & & \multirow{2}{*}{\multicolumn{2}{|c|}{0}} & & & & & & \\
\hline & & & & & \multicolumn{2}{|c|}{1} & \multicolumn{2}{|c|}{2} & \multicolumn{2}{|c|}{$\geq 3$} \\
\hline & Female & Male & Female & Male & Female & Male & Female & Male & Female & Male \\
\hline $\begin{array}{l}\text { Completely } \\
\text { agree }\end{array}$ & 20.6 & 21.5 & 27.0 & 26.5 & 18.4 & 17.5 & 13.0 & 11.3 & 11.9 & 17.5 \\
\hline Rather agree & 25.1 & 33.9 & 26.6 & 36.8 & 27.2 & 32.5 & 24.7 & 30.3 & 21.4 & 22.8 \\
\hline $\begin{array}{l}\text { Neither agree } \\
\text { nor disagree }\end{array}$ & 25.8 & 22.5 & 20.1 & 23.7 & 25.7 & 28.5 & 28.2 & 32.4 & 35.7 & 33.3 \\
\hline $\begin{array}{l}\text { Rather } \\
\text { disagree }\end{array}$ & 14.0 & 12.4 & 12.7 & 7.5 & 15.2 & 14.1 & 19.1 & 19.0 & 19.1 & 15.8 \\
\hline $\begin{array}{l}\text { Completely } \\
\text { disagree }\end{array}$ & 14.5 & 9.6 & 13.5 & 5.5 & 13.6 & 7.5 & 15.0 & 6.9 & 11.9 & 10.5 \\
\hline Total & 100.0 & 99.9 & 99.9 & 100.0 & 100.1 & 100.1 & 100.0 & 99.9 & 100.0 & 99.9 \\
\hline $\mathrm{N}$ & 613 & 613 & 259 & 253 & 1,101 & 1,032 & 607 & 620 & 42 & 57 \\
\hline$\chi^{2}(\mathrm{df}=4)$ & \multicolumn{2}{|c|}{$\begin{array}{l}16.245 \\
(0.003)\end{array}$} & \multicolumn{2}{|c|}{$\begin{array}{l}16.894 \\
(0.002)\end{array}$} & \multicolumn{2}{|c|}{$\begin{array}{l}26.228 \\
(0.000)\end{array}$} & \multicolumn{2}{|c|}{$\begin{array}{l}24.311 \\
(0.000)\end{array}$} & \multicolumn{2}{|c|}{$\begin{array}{c}0.759 \\
(0.944)\end{array}$} \\
\hline
\end{tabular}

Significance between childless respondents with an intimate friend and married or cohabiting childless respondents: females: $\chi^{2}=6.363$, sign $=0.174$; males: $\chi^{2}=9.891$, sign $=0.042$.

\section{Grater joy and satisfaction in respondent's life}

\begin{tabular}{|c|c|c|c|c|c|c|c|c|c|c|}
\hline & \multicolumn{10}{|c|}{ Kind of partnership } \\
\hline & \multirow{2}{*}{\multicolumn{2}{|c|}{$\begin{array}{c}\text { Intimate friend } \\
\text { Parity } \\
\end{array}$}} & \multicolumn{8}{|c|}{ Marriage or cohabitation } \\
\hline & & & & & & $\mathrm{Pal}$ & & & & \\
\hline & \multicolumn{2}{|c|}{0} & \multicolumn{2}{|c|}{0} & \multicolumn{2}{|c|}{1} & \multicolumn{2}{|c|}{2} & \multicolumn{2}{|c|}{$\geq 3$} \\
\hline & Female & Male & Female & Male & Female & Male & Female & Male & Female & Male \\
\hline $\begin{array}{l}\text { Completely } \\
\text { agree }\end{array}$ & 58.7 & 49.8 & 66.0 & 63.0 & 55.6 & 47.3 & 37.0 & 29.3 & 35.7 & 21.1 \\
\hline Rather agree & 31.4 & 38.5 & 25.5 & 30.3 & 33.2 & 39.4 & 39.8 & 42.7 & 28.6 & 36.8 \\
\hline $\begin{array}{l}\text { Neither agree } \\
\text { nor disagree }\end{array}$ & 6.3 & 8.3 & 3.5 & 3.2 & 7.8 & 9.3 & 14.1 & 19.2 & 21.4 & 26.3 \\
\hline $\begin{array}{l}\text { Rather } \\
\text { disagree }\end{array}$ & 1.8 & 1.7 & 2.7 & 1.6 & 1.8 & 1.9 & 6.9 & 6.8 & 9.5 & 10.5 \\
\hline $\begin{array}{l}\text { Completely } \\
\text { disagree }\end{array}$ & 1.8 & 1.7 & 2.3 & 2.0 & 1.6 & 2.2 & 2.1 & 2.0 & 4.8 & 5.3 \\
\hline Total & 100.0 & 100.0 & 100.0 & 100.1 & 100.0 & 100.1 & 99.9 & 100.0 & 100.0 & 100.0 \\
\hline $\mathrm{N}$ & 615 & 602 & 259 & 251 & 1,103 & 1,021 & 608 & 614 & 42 & 57 \\
\hline$\chi^{2}(\mathrm{df}=4)$ & & & & & & & & & & \\
\hline
\end{tabular}

Significance between childless respondents with an intimate friend and married or cohabiting childless respondents: females: $\chi^{2}=7.474$, sign $=0.113$; males: $\chi^{2}=15.961$, sign $=0.003$. 
A part of the respondent is continued into the future

\begin{tabular}{|c|c|c|c|c|c|c|c|c|c|c|}
\hline & \multicolumn{10}{|c|}{ Kind of partnership } \\
\hline & \multicolumn{4}{|c|}{ Intimate friend } & \multicolumn{4}{|c|}{ Marriage or cohabitation } & & \\
\hline & \multirow{2}{*}{\multicolumn{2}{|c|}{$\begin{array}{c}\text { Parity } \\
0\end{array}$}} & \multicolumn{8}{|c|}{ Parity } \\
\hline & & & \multicolumn{2}{|c|}{0} & \multicolumn{2}{|c|}{1} & \multicolumn{2}{|c|}{2} & \multicolumn{2}{|c|}{$\geq 3$} \\
\hline & Female & Male & Female & Male & Female & Male & Female & Male & Female & Male \\
\hline $\begin{array}{l}\text { Completely } \\
\text { agree }\end{array}$ & 62.3 & 57.2 & 61.6 & 62.2 & 56.6 & 50.4 & 43.0 & 41.3 & 55.0 & 39.3 \\
\hline Rather agree & 30.6 & 33.0 & 25.2 & 28.3 & 30.6 & 37.5 & 36.7 & 35.4 & 35.0 & 30.4 \\
\hline $\begin{array}{l}\text { Neither agree } \\
\text { nor disagree }\end{array}$ & 3.3 & 6.7 & 7.0 & 6.4 & 8.3 & 9.4 & 13.2 & 18.9 & 7.5 & 23.2 \\
\hline $\begin{array}{l}\text { Rather } \\
\text { disagree }\end{array}$ & 1.6 & 1.7 & 2.7 & 0.4 & 2.5 & 1.4 & 4.3 & 2.9 & 2.5 & 5.4 \\
\hline $\begin{array}{l}\text { Completely } \\
\text { disagree }\end{array}$ & 2.3 & 1.5 & 3.5 & 2.8 & 2.1 & 1.4 & 2.8 & 1.5 & -- & 1.8 \\
\hline Total & 100.1 & 100.1 & 100.0 & 100.1 & 100.1 & 100.1 & 100.0 & 100.0 & 100.0 & 99.9 \\
\hline $\mathrm{N}$ & 615 & 601 & 258 & 251 & 1,103 & 1,022 & 605 & 613 & 40 & 56 \\
\hline$\chi^{2}(\mathrm{df}=4)$ & \multicolumn{2}{|c|}{$\begin{array}{c}9.945 \\
(0.041)\end{array}$} & \multicolumn{2}{|c|}{$\begin{array}{c}5.066 \\
(0.281)\end{array}$} & \multicolumn{2}{|c|}{$\begin{array}{l}16.703 \\
(0.002)\end{array}$} & \multicolumn{2}{|c|}{$\begin{array}{l}10.629 \\
(0.031)\end{array}$} & \multicolumn{2}{|c|}{$\begin{array}{c}6.042 \\
(0.196)\end{array}$} \\
\hline
\end{tabular}

Significance between childless respondents with an intimate friend and married or cohabiting childless respondents: females: $\chi^{2}=9.734$, sign $=0.045$; males: $\chi^{2}=5.735$, sign $=0.220$. 


\section{Appendix B.2: Expected costs of having children by kind of partnership, parity, and gender}

\section{Increase of economic difficulties}

\begin{tabular}{|c|c|c|c|c|c|c|c|c|c|c|}
\hline & \multicolumn{10}{|c|}{ Kind of partnership } \\
\hline & \multirow{3}{*}{\multicolumn{2}{|c|}{$\begin{array}{c}\text { Intimate friend } \\
\text { Parity } \\
0\end{array}$}} & \multirow{2}{*}{\multicolumn{8}{|c|}{ Marriage or cohabitation }} \\
\hline & & & \multicolumn{4}{|c|}{ Parity } & & & & \\
\hline & & & \multicolumn{2}{|c|}{0} & \multicolumn{2}{|c|}{1} & \multicolumn{2}{|c|}{2} & \multicolumn{2}{|c|}{$\geq 3$} \\
\hline & Female & Male & Female & Male & Female & Male & Female & Male & Female & Male \\
\hline $\begin{array}{l}\text { Completely } \\
\text { agree }\end{array}$ & 39.3 & 38.2 & 45.6 & 33.2 & 44.5 & 39.5 & 55.3 & 50.2 & 71.4 & 52.6 \\
\hline Rather agree & 39.1 & 43.6 & 29.7 & 38.3 & 34.5 & 38.4 & 33.1 & 34.3 & 19.1 & 26.3 \\
\hline $\begin{array}{l}\text { Neither agree } \\
\text { nor disagree }\end{array}$ & 8.5 & 7.3 & 8.1 & 13.0 & 9.4 & 10.7 & 5.6 & 7.1 & 4.8 & 10.5 \\
\hline $\begin{array}{l}\text { Rather } \\
\text { disagree }\end{array}$ & 7.8 & 6.2 & 10.0 & 11.5 & 7.4 & 6.6 & 3.3 & 5.5 & 2.4 & 5.3 \\
\hline $\begin{array}{l}\text { Completely } \\
\text { disagree }\end{array}$ & 5.4 & 4.7 & 6.6 & 4.0 & 4.1 & 4.8 & 2.8 & 2.9 & 2.4 & 5.3 \\
\hline Total & 100.1 & 100.0 & 100.0 & 100.0 & 99.9 & 100.0 & 100.1 & 100.0 & 100.1 & 100.0 \\
\hline $\mathrm{N}$ & 614 & 615 & 259 & 253 & 1,103 & 1,032 & 608 & 621 & 42 & 57 \\
\hline$\chi^{2}(\mathrm{df}=4)$ & \multicolumn{2}{|c|}{$\begin{array}{c}3.544 \\
(0.471)\end{array}$} & \multicolumn{2}{|c|}{$\begin{array}{l}12.598 \\
(0.013)\end{array}$} & \multicolumn{2}{|c|}{$\begin{array}{c}7.338 \\
(0.119) \\
\end{array}$} & \multicolumn{2}{|c|}{$\begin{array}{c}6.040 \\
(0.196)\end{array}$} & \multicolumn{2}{|c|}{$\begin{array}{c}3.948 \\
(0.413) \\
\end{array}$} \\
\hline
\end{tabular}

Significance between childless respondents with an intimate friend and married or cohabiting childless respondents: females: $\chi^{2}=7.695$, sign $=0.103$; males: $\chi^{2}=15.650$, sign $=0.004$.

\section{Greater worries and preoccupations in daily life}

\begin{tabular}{|c|c|c|c|c|c|c|c|c|c|c|}
\hline & \multicolumn{10}{|c|}{ Kind of partnership } \\
\hline & \multirow{2}{*}{\multicolumn{2}{|c|}{$\begin{array}{c}\text { Intimate friend } \\
\text { Parity }\end{array}$}} & \multicolumn{8}{|c|}{ Marriage or cohabitation } \\
\hline & & & \multicolumn{8}{|c|}{ Parity } \\
\hline & \multicolumn{2}{|c|}{0} & \multicolumn{2}{|c|}{0} & \multicolumn{2}{|c|}{1} & \multicolumn{2}{|c|}{2} & \multicolumn{2}{|c|}{$\geq 3$} \\
\hline & Female & Male & Female & Male & Female & Male & Female & Male & Female & Male \\
\hline $\begin{array}{l}\text { Completely } \\
\text { agree }\end{array}$ & 38.2 & 33.2 & 37.5 & 22.7 & 37.1 & 26.4 & 42.5 & 32.3 & 40.5 & 33.3 \\
\hline Rather agree & 43.3 & 42.2 & 35.9 & 45.0 & 43.3 & 41.5 & 41.7 & 46.1 & 45.2 & 40.4 \\
\hline $\begin{array}{l}\text { Neither agree } \\
\text { nor disagree }\end{array}$ & 10.0 & 12.6 & 11.6 & 14.7 & 7.9 & 17.3 & 9.6 & 13.0 & 7.1 & 19.3 \\
\hline $\begin{array}{l}\text { Rather } \\
\text { disagree }\end{array}$ & 5.1 & 8.8 & 8.5 & 14.7 & 7.2 & 10.5 & 4.0 & 6.0 & 4.8 & 5.3 \\
\hline $\begin{array}{l}\text { Completely } \\
\text { disagree }\end{array}$ & 3.4 & 3.2 & 6.6 & 2.8 & 4.5 & 4.3 & 2.3 & 2.6 & 2.4 & 1.8 \\
\hline Total & 100.0 & 100.0 & 100.1 & 99.9 & 100.0 & 100.0 & 100.1 & 100.0 & 100.0 & 100.1 \\
\hline $\mathrm{N}$ & 612 & 602 & 259 & 251 & 1,103 & 1,021 & 607 & 614 & 42 & 57 \\
\hline$\chi^{2}(\mathrm{df}=4)$ & $\begin{array}{l}10 . \\
(0 .\end{array}$ & & & & & & & & & \\
\hline
\end{tabular}

Significance between childless respondents with an intimate friend and married or cohabiting childless respondents: females: $\chi^{2}=10.513$, sign $=0.033$; males: $\chi^{2}=13.423$, sign $=0.009$. 
Less time for personal interests and contacts with friends

\begin{tabular}{|c|c|c|c|c|c|c|c|c|c|c|}
\hline & \multicolumn{10}{|c|}{ Kind of partnership } \\
\hline & \multicolumn{2}{|c|}{ Intimate friend } & \multicolumn{8}{|c|}{ Marriage or cohabitation } \\
\hline & \multicolumn{2}{|c|}{ Parity } & \multicolumn{8}{|c|}{ Parity } \\
\hline & \multicolumn{2}{|c|}{0} & \multicolumn{2}{|c|}{0} & \multicolumn{2}{|c|}{1} & \multicolumn{2}{|c|}{2} & \multicolumn{2}{|c|}{$\geq 3$} \\
\hline & Female & Male & Female & Male & Female & Male & Female & Male & Female & Male \\
\hline $\begin{array}{l}\text { Completely } \\
\text { agree }\end{array}$ & 33.0 & 30.9 & 32.4 & 21.2 & 34.0 & 20.5 & 37.1 & 24.7 & 31.0 & 19.3 \\
\hline Rather agree & 45.2 & 41.1 & 37.5 & 44.4 & 40.3 & 39.5 & 41.4 & 43.1 & 47.6 & 31.6 \\
\hline $\begin{array}{l}\text { Neither agree } \\
\text { nor disagree }\end{array}$ & 11.1 & 15.0 & 12.7 & 16.8 & 10.4 & 20.7 & 12.0 & 19.2 & 14.3 & 22.8 \\
\hline $\begin{array}{l}\text { Rather } \\
\text { disagree }\end{array}$ & 6.3 & 10.0 & 12.7 & 14.0 & 9.6 & 13.9 & 6.1 & 9.6 & 4.8 & 19.3 \\
\hline $\begin{array}{l}\text { Completely } \\
\text { disagree }\end{array}$ & 4.4 & 3.0 & 4.6 & 3.6 & 5.6 & 5.5 & 3.5 & 3.4 & 2.4 & 7.0 \\
\hline Total & 100.0 & 100.0 & 99.9 & 100.0 . & 99.9 & 100.1 & 100.1 & 100.0 & 100.1 & 100.0 \\
\hline $\mathrm{N}$ & 615 & 601 & 259 & 250 & 1,103 & 1,022 & 607 & 615 & 42 & 57 \\
\hline$\chi^{2}(\mathrm{df}=4)$ & \multicolumn{2}{|c|}{$\begin{array}{l}11.732 \\
(0.019)\end{array}$} & \multicolumn{2}{|c|}{$\begin{array}{c}9.368 \\
(0.053)\end{array}$} & \multicolumn{2}{|c|}{$\begin{array}{l}79.994 \\
(0.000)\end{array}$} & \multicolumn{2}{|c|}{$\begin{array}{l}30.108 \\
(0.000)\end{array}$} & \multicolumn{2}{|c|}{$\begin{array}{c}8.811 \\
(0.066)\end{array}$} \\
\hline
\end{tabular}

Significance between childless respondents with an intimate friend and married or cohabiting childless respondents: females: $\chi^{2}=12.103$, sign $=0.017$; males: $\chi^{2}=9.566$, sign $=0.048$.

\section{Fewer opportunities in working career and/or higher education}

\begin{tabular}{|c|c|c|c|c|c|c|c|c|c|c|}
\hline & \multicolumn{10}{|c|}{ Kind of partnership } \\
\hline & \multirow{2}{*}{\multicolumn{2}{|c|}{$\begin{array}{c}\text { Intimate friend } \\
\text { Parity } \\
\end{array}$}} & \multirow{2}{*}{\multicolumn{8}{|c|}{$\begin{array}{c}\text { Marriage or cohabitation } \\
\text { Parity }\end{array}$}} \\
\hline & & & & & & & & & & \\
\hline & \multicolumn{2}{|c|}{0} & \multicolumn{2}{|c|}{0} & \multicolumn{2}{|c|}{1} & \multicolumn{2}{|c|}{2} & \multicolumn{2}{|c|}{$\geq 3$} \\
\hline & Female & Male & Female & Male & Female & Male & Female & Male & Female & Male \\
\hline $\begin{array}{l}\text { Completely } \\
\text { agree }\end{array}$ & 25.1 & 12.5 & 22.0 & 7.5 & 22.9 & 8.1 & 28.8 & 9.7 & 31.0 & 19.3 \\
\hline Rather agree & 32.7 & 18.1 & 25.5 & 8.7 & 26.1 & 13.2 & 24.8 & 16.8 & 47.6 & 31.6 \\
\hline $\begin{array}{l}\text { Neither agree } \\
\text { nor disagree }\end{array}$ & 11.1 & 16.1 & 7.7 & 15.8 & 12.3 & 17.3 & 13.2 & 18.9 & 14.3 & 22.8 \\
\hline $\begin{array}{l}\text { Rather } \\
\text { disagree }\end{array}$ & 18.2 & 28.3 & 22.8 & 35.6 & 21.6 & 31.4 & 20.4 & 30.0 & 4.8 & 19.3 \\
\hline $\begin{array}{l}\text { Completely } \\
\text { disagree }\end{array}$ & 12.9 & 24.9 & 22.0 & 32.4 & 17.1 & 30.0 & 12.8 & 24.6 & 2.4 & 7.0 \\
\hline Total & 100.0 & 99.9 & 100.0 & 100.0 & 100.0 & 100.0 & 100.0 & 100.0 & 100.1 & 100.0 \\
\hline $\mathrm{N}$ & 614 & 614 & 259 & 253 & 1,102 & 1,032 & 608 & 619 & 42 & 57 \\
\hline$\chi^{2}(\mathrm{df}=4)$ & \multicolumn{2}{|c|}{$\begin{array}{l}94.427 \\
(0.000)\end{array}$} & \multicolumn{2}{|c|}{$\begin{array}{c}9.368 \\
(0.053) \\
\end{array}$} & \multicolumn{2}{|c|}{$\begin{array}{l}79.994 \\
(0.000)\end{array}$} & \multicolumn{2}{|c|}{$\begin{array}{l}30.108 \\
(0.000)\end{array}$} & \multicolumn{2}{|c|}{$\begin{array}{c}8.811 \\
(0.066) \\
\end{array}$} \\
\hline
\end{tabular}

Significance between childless respondents with an intimate friend and married or cohabiting childless respondents: females: $\chi^{2}=17.564$, sign $=0.002$; males: $\chi^{2}=21.179$, sign $=0.000$. 
Increase of the physical burden because of pregnancy, care for the baby, or breastfeeding

\begin{tabular}{|c|c|c|c|c|c|c|c|c|c|c|}
\hline & \multicolumn{10}{|c|}{ Kind of relationship } \\
\hline & \multirow{2}{*}{\multicolumn{2}{|c|}{$\begin{array}{c}\text { Intimate friend } \\
\text { Parity }\end{array}$}} & \multicolumn{8}{|c|}{ Marriage or cohabitation } \\
\hline & & & \multicolumn{8}{|c|}{ Parity } \\
\hline & \multicolumn{2}{|c|}{0} & \multicolumn{2}{|c|}{0} & \multicolumn{2}{|c|}{1} & \multicolumn{2}{|c|}{2} & \multicolumn{2}{|c|}{$\geq 3$} \\
\hline & Female & Male & Female & Male & Female & Male & Female & Male & Female & Male \\
\hline $\begin{array}{l}\text { Completely } \\
\text { agree }\end{array}$ & 24.7 & -- & 22.4 & -- & 23.8 & -- & 34.6 & -- & 43.9 & -- \\
\hline Rather agree & 31.2 & -- & 27.8 & -- & 31.8 & -- & 34.9 & -- & 31.7 & -- \\
\hline $\begin{array}{l}\text { Neither agree } \\
\text { nor disagree }\end{array}$ & 13.0 & -- & 8.9 & -- & 10.6 & -- & 9.9 & -- & 7.3 & -- \\
\hline $\begin{array}{l}\text { Rather } \\
\text { disagree }\end{array}$ & 15.5 & -- & 17.0 & -- & 17.2 & -- & 12.2 & -- & 7.3 & -- \\
\hline $\begin{array}{l}\text { Completely } \\
\text { disagree }\end{array}$ & 15.6 & -- & 23.9 & -- & 16.6 & -- & 8.4 & -- & 9.8 & -- \\
\hline Total & 100.0 & -- & 100.0 & -- & 100.0 & -- & 100.0 & -- & 100.0 & -- \\
\hline $\mathrm{N}$ & 615 & -- & 259 & -- & 1,097 & -- & 605 & -- & 41 & -- \\
\hline$\chi^{2}(\mathrm{df}=4)$ & \multicolumn{2}{|c|}{--} & \multicolumn{2}{|c|}{--} & \multicolumn{2}{|c|}{--} & \multicolumn{2}{|c|}{--} & \multicolumn{2}{|c|}{--} \\
\hline
\end{tabular}

Significance between childless respondents with an intimate friend and married or cohabiting childless respondents: females: $\chi^{2}=11.015$, sign $=0.026$. 